\title{
The New American Debtors' Prisons
}

\section{Citation}

Christopher D. Hampson, The New American Debtors' Prisons (Harvard Law School 2015 Stephen L. Werner Prize: Criminal Justice, Aug. 4, 2015).

\section{Permanent link}

http://nrs.harvard.edu/urn-3:HUL.InstRepos:17840773

\section{Terms of Use}

This article was downloaded from Harvard University's DASH repository, and is made available under the terms and conditions applicable to Other Posted Material, as set forth at http:// nrs.harvard.edu/urn-3:HUL.InstRepos:dash.current.terms-of-use\#LAA

\section{Share Your Story}

The Harvard community has made this article openly available.

Please share how this access benefits you. Submit a story.

Accessibility 


\title{
THE NEW AMERICAN DEBTORS' PRISONS
}

\author{
Christopher D. Hampson*
}

Debtors' prisons are back, in the form of imprisonment for nonpayment of criminal fines, fees, and costs. While the new debtors' prisons are not historically or doctrinally continuous with the old, recent developments in criminal law suggest that some parts of them offend the same functional and moral principles that compelled the abolition of the old debtors' prisons. Legal actors may therefore plausibly interpret the constitutional and statutory texts that abolished the old debtors' prisons to constitute checks on the new - or a new abolitionist movement might deploy new constitutional texts. While the criminal law literature is starting to grapple with the question of debtors' prisons, this piece engages with the metaphor head-on and asks how the old ban on debtors' prisons should be reinterpreted for a new era of mass incarceration.

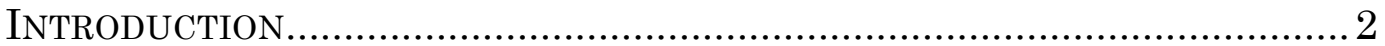

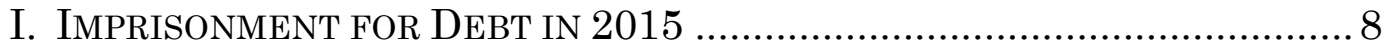

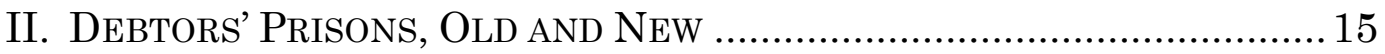

A. The Old Debtors' Prisons: Qualities and Function ....................... 15

B. The Abolition Movement: Purpose and Limits............................ 19

1. Functional Reasons for the Ban ..............................................25

2. Doctrinal Limits on the Ban..................................................22

C. The True Historical Antecedents .................................................29

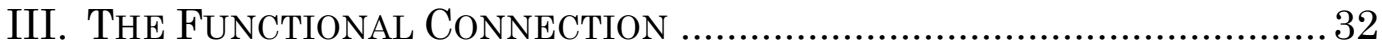

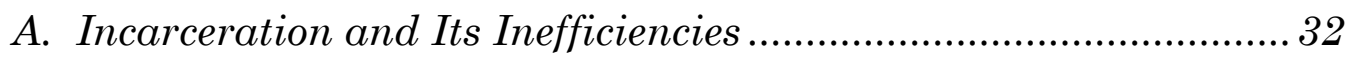

B. Civil Debts in Criminal Law ....................................................... 34

C. Crime, Contract and Situationism .............................................. 36

IV. REINVIGORATING THE BAN........................................................ 37

A. The Indigent/Nonindigent Line: Bearden Claims ....................... 37

B. The Civil/Criminal Line: Imprisonment-for-Debt Claims .......... 42

* J.D., M.T.S., Harvard Law School, Harvard Divinity School, 2016. Law Clerk, Hon. Richard A. Posner, U.S. Seventh Circuit Court of Appeals, starting 2016. Winner of the 2015 Steven L. Werner Writing Prize in Criminal Justice, Harvard Law School. This Article has come together over more than a year of ruminations with legal scholars and practitioners. Many thanks go to Yonathan Arbel, Alec Karakatsanis, Bruce Mann, Oren Bar-Gill, Andrew Crespo, Henry Smith, Adrian Vermeule, David Skeel, Richard Fallon, Christine Desan, Sven Beckert, Jacob Goldin, Rachel Sachs, and Mark Jia for insightful discussions and comments. Any errors that remain are my own. My deepest gratitude to Cecilia, Olivia, and Jonathan for their love and patience during the writing process. 
1. Expanding the Scope of the Ban .............................................. 42

a. Strict Liability Offenses ........................................................ 42

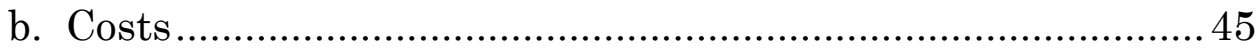

2. Applying Its Protections .......................................................... 49

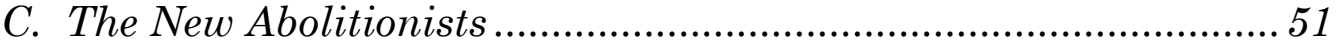

D. Chilling "Credit" \& Backlash ...................................................... 53

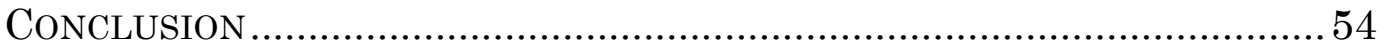

\section{INTRODUCTION}

ebtors' prisons are back. Or, at least, something like them.
Over the past several years, Americans have witnessed the
mass incarceration of debtors for failure to pay monetary obligations owed to the state, usually municipalities and usually stemming from low-level criminal behavior, such as traffic violations, shoplifting, prostitution, and domestic disputes. ${ }^{1}$ The rising issue has been noted by a wide variety of voices, including students of law, ${ }^{2}$ litigators, ${ }^{3}$ journalists, ${ }^{4}$ and even political satirists. ${ }^{5}$ In some ways, we're seeing the unhappy return to the outmoded and unsavory practice of imprisonment for debt, ${ }^{6}$ perhaps most famously portrayed

${ }^{1}$ See Telephone Interview with Douglas K. Wilson, Colorado Public Defender (Oct. 21, 2014) (on file with [Redacted] Law School library).

2 See, e.g., Sarah Dolisca Bellacicco, Safe Haven No Longer: The Role of Georgia Courts and Private Probation Companies in Sustaining a De Facto Debtors' Prison System, 48 GA. L. REV. 227, 234 (2014).

${ }^{3}$ See, e.g., Civil Rights Attorneys Sue Ferguson Over "Debtors Prisons" (NPR radio broadcast 2015) ("[W]e've seen the rise of modern American debtors' prisons and nowhere is that phenomenon more stark than in the Ferguson and Jennings municipal courts and municipal jails."), available at http://www.npr.org/blogs/codeswitch/2015/02/08/384332798/civil-rights-attorneys-sueferguson-over-debtors-prisons; Alec Karakatsanis, Policing, Mass Imprisonment, and the Failure of American Lawyers, 128 HARV. L. REV. F. 253, 262-63 (2015) ("The rise of modern debtors' prisons is a phenomenon affecting hundreds of thousands of people all over the country, and it is happening almost entirely outside of the public consciousness.").

${ }^{4}$ See, e.g., Sarah Stillman, The New Yorker, Get Out of Jail, Inc. (June 23, 2014), http://www.newyorker.com/magazine/2014/06/23/get-out-of-jail-inc; The New Debtors' Prisons; Criminal Justice (2), THE ECONOMIST (Nov. 16, 2013), available at http://www.economist.com/news/united-states/21589903-if-you-are-poor-dont-getcaught-speeding-new-debtors-prisons.

${ }^{5}$ See Last Week Tonight with John Oliver (HBO television broadcast Mar. 22, 2015), https://www.youtube.com/watch?v=0UjpmT5noto; The Colbert Report (Comedy Central television broadcast June 11, 2014), http://thecolbertreport.cc.com/videos/m87g43/the-word---debt-or-prison.

${ }_{6}^{6}$ See, e.g., Alex Tabarrok, Marginal Revolution, Debtor's Prison for Failure to Pay for Your Trial (Apr. 18, 2012), 
by Charles Dickens in works like David Copperfield.7 "The State of Georgia has come a long way since it was founded as a safe haven for debtors," laments a student commentator. 8 "Yes, America, we have returned to debtors' prisons," declares one sociologist. 9

Take the story of Harriet Cleveland as a window into the problem: Cleveland, a forty-nine-year old mother of three, ${ }^{10}$ was laid off from her job at a day care in 2009. ${ }^{11}$ Between 2008 and 2009, Cleveland received several traffic tickets at a police roadblock in her Montgomery neighborhood for operating her vehicle without the appropriate insurance. ${ }^{12}$ After her license was suspended due to her nonpayment of the ensuing fines and court costs, she continued to drive to work and her child's school, incurring more debt to Montgomery for driving without a license. ${ }^{13}$ Over the course of several years, Cleveland attempted to "chip[] away" at her debt - while collection fees and other surcharges ballooned it up behind her back. ${ }^{14}$ On August 20, 2013, Cleveland was arrested at her home, while babysitting her twoyear-old grandson. ${ }^{15}$ The next day, a municipal judge ordered her to pay $\$ 1,554$ or spend thirty-one days in jail. ${ }^{16}$ She had no choice but to "sit out" her debt — at the rate of $\$ 50$ per day. ${ }^{17}$ In prison, she slept on the floor, using "old blankets to block the sewage from a leaking

http://marginalrevolution.com/marginalrevolution/2012/04/debtors-prison-for-failureto-pay-for-your-own-trial.html.

7 See, e.g., The New Debtors' Prisons, The N.Y. Times (Apr. 5, 2009), http://www.nytimes.com/2009/04/06/opinion/06mon4.html. The two novels cited most frequently seem to be David Copperfield (1850) and Little Dorrit (1857). However, the specter of the debtors' prison lurks in the shadows even of Dickens's classic $A$ Christmas Carol. Those who did not pay the debts so meticulously recorded by the shivering Bob Cratchit could have been thrown in prison by Scrooge - part of why he was so hated and feared by his debtors. See ChARLEs DiCKEns, A Christmas CAROL 58 (Dover Publications, 1991) (“[B]efore [our debt is transferred from Scrooge] we shall be ready with the money; and even though we were not, it would be bad fortune indeed to find so merciless a creditor in his successor.").

${ }^{8}$ Bellacicco, supra note 2, at 266.

9 Alexes Harris, LATimes.Com, Yes, America, We Have Returned to Debtor's Prisons (June 6, 2014), http://www.latimes.com/opinion/op-ed/la-oe-harris-criminal-fines20140608-story.html.

10 See Stillman, supra note 4.

11 Amended Complaint at 1, Cleveland v. Montgomery (Case No. 2:13-cv-00732-MEFTFM) [hereinafter Complaint, Cleveland $v$. Montgomery], available at http://www.splcenter.org/sites/default/files/downloads/case/amended_complaint-

_harriet_cleveland_0.pdf.

$12 I d$.

${ }^{13} I d$.

14 See Stillman, supra note 4.

${ }^{15}$ Complaint, Cleveland v. Montgomery, supra note 11, at 1; Stillman, supra note 4.

${ }_{16}$ Complaint, Cleveland v. Montgomery, supra note 11, at 2.

17 See id. at 7. 
toilet."18 After Cleveland sued the city, aided by the Southern Poverty Legal Center, ${ }^{19}$ they settled. ${ }^{20}$

The problem is widespread. In Colorado, the shoplifting offense of Linda Roberts - $\$ 21$ worth of food - resulted in $\$ 746$ of court costs, fines, fees, and restitution. ${ }^{21}$ Ms. Roberts, who lived exclusively on SNAP benefits and a Social Security disability check, sat out her debt for fifteen days in jail. ${ }^{22}$ And in Georgia, Tom Barrett was sentenced to twelve months of probation for stealing a can of beer. ${ }^{23}$ But six months in, when he had resorted to selling his own blood plasma and still couldn't pay the costs - including a $\$ 12$ per day ankle bracelet, a $\$ 50$ set-up fee, and $\$ 39$ per month to a private probation company - Mr. Barrett faced imprisonment. ${ }^{24}$ It's not just a handful of states, either: Required indigency inquiries were markedly absent in Louisiana, Michigan, Ohio, Georgia, and Washington, a 2010 ACLU report claimed. $^{25}$ And a 2011 Brennan Center report flagged up unsavory "criminal justice debt" practices in fifteen states, including California, Texas, Michigan, Pennsylvania, and New York. ${ }^{26}$

And the problem is pervasive, at least in some places. The best evidence to date is the Department of Justice's 2015 report on the Ferguson police department. The DOJ's investigation revealed that Ferguson law enforcement — including both policing and the municipal court - was deployed to raise revenue. ${ }^{27}$ And they were

\footnotetext{
18 See Stillman, supra note 4.

19 See id.

20 See Joint Settlement Agreement, Cleveland v. Montgomery (Case No. 2:13-cv00732-MEF-TFM), available

at http://www.splcenter.org/sites/default/files/downloads/case/exhibit_a_to_joint_settlem ent_agreement_-_judicial_procedures-_140912.pdf.

${ }^{21} \mathrm{Id}$.

${ }^{22} I d$.

${ }^{23}$ Joseph Shapiro, Measures Aimed at Keeping People Out of Jail Punish the Poor, NPR.ORG (May 24, 2014),http://www.npr.org/2014/05/24/314866421/measures-aimedat-keeping-people-out-of-jail-punish-the-poor.

${ }^{24} I d$.

25 See ACLU, In for a Penny: The Rise of America's New Debtors' Prisons (2010), https://www.aclu.org/files/assets/InForAPenny_web.pdf.

26 See Alicia Bannon et Al., Brennan Center for Justice, Criminal Justice DEBT: A BARRIER TO REENTRY 6 (2010), http://www.brennancenter.org/sites/default /files/legacy/Fees\%20and\%20Fines\%20FINAL.pdf.

27 See Department of Justice, Investigation of the Ferguson Police DEPARTMENT 9 (2015) ("City officials have consistently set maximizing revenue as the priority for Ferguson's law enforcement activity."); id. at 3 ("Ferguson has allowed its focus on revenue generation to fundamentally compromise the role of Ferguson's municipal court.").
} 
quite hawkish about it. In March 2010, the city's Finance Director emailed the following to Police Chief Jackson:

$[U] n l e s s$ ticket writing ramps up significantly before the end of the year, it will be hard to significantly raise collections next year. What are your thoughts? Given that we are looking at a substantial sales tax shortfall, it's not an insignificant issue. ${ }^{28}$

In 2013, the Ferguson municipal court issued over 9,000 warrants for failure to pay fines and fees connected to such "minor violations . . . as parking infractions, traffic tickets, [and] housing code violations." 29 Ferguson was also in the practice of adding fines and fees for missed appearances and missed payments - and of using arrest warrants as a collection device. ${ }^{30}$ Coupled with a pattern of unconstitutional (and racially discriminatory) stops and arrests, 31 heavy fines, ${ }^{32}$ and misleading information about court dates, ${ }^{33}$ these court practices produced one of the most troubling debtors' prisons yet studied.

Harriet Cleveland, Linda Roberts, and Tom Barrett all passed through the new American "debtors' prisons." As it turns out, though, imprisonment for nonpayment of debt - debtors' prison - is much more complex a concept than it initially seems. Take the definition piece by piece: (a) Imprisonment - usually understood as a tighter confinement than restrictions on travel or economic liberty, ${ }^{34}$ the debtors might either be held in a separate wing or a separate institution, or confined alongside the general criminal population. (b) Nonpayment - often (but not always) the debtor is viewed as "holding the keys to his cell," which means nonpayment means willful nonpayment. Thus the ability-to-pay hearing, and its procedural timing, has always been central to the debate over debtors' prisons. (c) For - the sanction is either deployed either to coerce the debtor to pay the debt out of concealed or otherwise exempt assets, ${ }^{35}$ or it is deployed

$28 \mathrm{Id}$. at 10.

${ }^{29} \mathrm{Id}$. at 3.

30 See id. at 42.

31 See id. at 18.

32 See id. at 53.

33 See id. at 46.

${ }^{34}$ But see Danshera Cords, Lien on Me: Virtual Debtors Prisons, the Practical Effects of Tax Liens and Proposals for Reform, 49 U. Louisville L. REV. 1, 24 (2011) (arguing that unpaid tax liens clouding a taxpayer's credit report "indefinitely puts the taxpayer in a kind of 'virtual debtor's prison."); John B. Mitchell and Kelly Kunsch, Of Driver's Licenses and Debtor's Prison, 4 SEATTLE J. Soc. Just. 439 (2005) (discussing threat of taking away drivers' licenses to enforce repayment of debt).

35 More unsavory forms of collection actions, like debtors' prison, might induce a debtor "voluntarily" to make payment out of property that creditors cannot attach directly, or income they cannot garnish. Every state has an exemption statute protecting a core amount of the debtors' property from collection actions. See, e.g., 9 R.I. GEN. LAWS § 9-26-4 (2015); id. § 9-26-4.1. 
to punish the debtor for nonpayment. (d) Debt - money obligations have a wide variety of sources, and the law has distinguished between debts stemming from contract, torts of negligence, intentional torts, familial obligations like alimony and child support payments, tax, government-provided services, criminal fines, criminal fees, and costs. Along multiple of these axes, the extent to which what's happening today is similar to the practices of the past is not immediately obvious.

This Article is a broad response to the modern-day debtors' prisons: it compares the old and new institutions, covers recent litigation strategy, and proposes legal regimes to ameliorate the problem.

With regard to the comparison, the Article makes a two-step argument. First, on the surface, the new American debtors' prisons aren't like the old at all. The old debtors' prisons dealt exclusively with contractual, commercial debt and typically held debtors in separate institutions. The new debtors' prisons deal with debt stemming from crime (different 1L class, different policy goals) and confine debtors alongside the general prison population. The abolitionist movement of the nineteenth century - which ultimately produced forty-one state constitutional bans and a whole host of subconstitutional checks on imprisonment for debt - stopped well short of abolishing these debtors' prisons. Where there wasn't a textual carve-out for criminal debts in the statutory and constitutional bans, the subsequent caselaw readily wrote it in.

And yet - while the old and new debtors' prisons are neither doctrinally nor historically connected, the Article contends that they're still related, but on a deeper, functional level. First, regardless of whether the breach sounds in contract or crime, imprisonment as a remedy is an extremely blunt sanction liable to create massive inefficiencies - especially when there are less costly alternatives. Second, a huge chunk of debts stemming from crime, namely, strict liability offenses and costs, have a distinctly civil feel to them and therefore trigger policy concerns more similar to those raised by commercial debt. Third, the nineteenth-century abolitionist movement was fueled by a growing sense that punishing breach of contract was unreasonable in a rapidly expanding commercial society in which it became clear financial obligations weren't always under the control of debtors and creditors. Likewise, recent developments in our understanding of crime in an era of mass incarceration ${ }^{36}$ suggest we

36 That we have witnessed a period of mass incarceration in America is well known. But there is some evidence that a rollback on mass incarceration is underway. See 
should begin to feel similarly about certain areas of our criminal law, particularly those linked by sociologists to poverty and race.

These deeper rationales indicate the new debtors' prisons should be abolished as were the old. Mass incarceration should force us to ask a number of difficult questions about the way we punish. But at least some of those questions - those related to debtors' prisons - bring us back to a public conversation we've already had.

While the pathologies of contemporary American criminal law are well-known, this Article seems to be the first to engage with the new American debtors' prisons as such, ${ }^{37}$ analyzing their relationship to the debtors' prisons of the nineteenth century and exploring to what extent the legal texts that banned them have teeth today. By contrast, previous scholarly literature on the topic has either been tightly constrained in geographic scope ${ }^{38}$ or has grappled with the problem through the lens of federal Equal Protection and Due Process jurisprudence. ${ }^{39}$

Alexandra Natapoff, Misdemeanor Decriminalization, 68 VAND. L. REV. 1055, 1056 (2015).

37 Almost forty years ago, the literature saw a one-page analysis in a student Note, see Derek A. Westen, Fines, Imprisonment, and the Poor: "Thirty Dollars or Thirty Days," 57 CAL. L. REV. 778 (1969), which - without mentioning the term "debtors' prisons" - lightly touched on the imprisonment-for-debt provisions but ultimately concluded criminal and contractual debts are readily distinguishable, see id. at 80607. Westen spends most of his analysis on federal constitutional law. See id. at 796806. Similarly, an address by Justice Goldberg, reprinted in 1964, only hinted at the abolition of imprisonment for debt, expending more energy on moral and (federal) constitutional principles. See Arthur J. Goldberg, Equality and Governmental Action, 39 N.Y.U. L. REV. 205, 221 (1964) ("The 'choice' of paying $\$ 100$ fine or spending 30 days in jail is really no choice at all to the person who cannot raise $\$ 100$. The resulting imprisonment is no more or no less than imprisonment for being poor, a doctrine which I trust this Nation has long since outgrown.").

38 See Bellacicco, supra note 2 (discussing Georgia); Becky A. Vogt, State v. Allison: Imprisonment for Debt in South Dakota, 46 S.D. L. REV. 334, 2001 (discussing South Dakota); Kary L. Moss, Debtors' Prison in Michigan: The ACLU Takes up the Cause, 89 Mich. B.J. 40 (2010); Michael L. Vander Giessen, Note, Legislative Reforms for Washington State's Criminal Monetary Penalties, 47 GonZaGa L. REV. 547 (2012).

39 See, e.g., Bellacicco, supra note 2, at 250-61 (arguing that the new debtors' prisons constitute a violation of the Equal Protection Clause, the Due Process Clause, and the Excessive Fines Clause); Ann K. Wagner, The Conflict over Bearden v. Georgia in State Courts: Plea-Bargained Probation Terms and the Specter of Debtors' Prison, 2010 U. CHI. Legal. F. 383. This is true as well of Professor Alexandra Natapoff's excellent recent piece, Natapoff, supra note 36, , which uses the term, see id. at 1101, and discusses the relevant federal equal protection law, see id. at 1082-85. The historical debtors' prisons and the state bans are not a focus of Natapoff's article, however. 
Of course, imprisonment for criminal debt could also falter elsewhere, say on the Eighth Amendment. ${ }^{40}$ That's not our concern here, ${ }^{41}$ although such inquiries are worthwhile. Instead, this piece focuses on today's debtors' prisons through the rich doctrinal and historical context of the abolition of the historical institutions and the legal texts it produced.

The Article proceeds as follows. Part I reports on the new debtors' prisons in greater depth, pulling out their common features and why, absent rigorous pushback, they're here to stay. Part II provides a historical introduction to the old debtors' prisons and their abolition, showing how the new and the old are doctrinally distinguishable and historically discontinuous. Part III lays out three areas in which the functions and morals of the nineteenth-century abolition still carry lessons for us today. And Part IV sketches out a doctrinal map to suggest how current law could be used to cut back on the new American debtors' prisons - and where new legal texts could productively be deployed.

\section{IMPRISONMENT FOR DEBT IN 2015}

There is nothing new under the sun: legal commentators have been concerned about imprisonment for criminal debt since at least the 1960s. ${ }^{42}$ But the problem has become especially severe, it seems,

\footnotetext{
40 See, e.g., Nicholas M. McLean, Livelihood, Ability to Pay, and the Original Meaning of the Excessive Fines Clause, 40 HASTINGS Const. L.Q. 833 (2013) (discussing excessive fines jurisprudence after United States. v. Bajakajian, 542 U.S. 321 (1998)). 41 Another argument that raises similar themes is the late Professor Vern Countryman's case that involuntary (or quasi-involuntary) Chapter 13 bankruptcy for individual debtors, which includes a payment plan from future wages, violates the Thirteenth Amendment. See Vern Countryman, Bankruptcy and the Individual Debtor-And a Modest Proposal to Return to the Seventeenth Century, 32 CATH. U. L. REV. 809, 826-27 (1983). Professor Margaret Howard has raised the same argument in the wake of involuntary repayment plans in the 2005 amendments to the Bankruptcy Code, comparing the analysis to that of imprisonment for debt. See Margaret Howard, Bankruptcy Bondage, 2009 U. ILL. L. REV. 191, 231-32. But while themes of slavery, race, and debt are present in this Article, the only constitutional texts engaged with in this piece are the Fifth and Fourteenth Amendments to the U.S. Constitution and the imprisonment-for-debt provisions in most state constitutions. A Thirteenth Amendment violation, however, could of course be found if forced labor were at issue, see infra n.56 and accompanying text, an analytically distinct problem better saved for another day.

42 See Westen, supra note 37, at 787 n.79 (citing sources); see also Ecclesiastes 1:9.
} 
within the past five years. ${ }^{43}$ In 2015, nonprofits Equal Justice Under Law and Arch City Defenders sued the cities of Ferguson ${ }^{44}$ and Jennings, ${ }^{45}$ Missouri, alleging that they were running the equivalent of a modern debtors' prison. 46 The Ferguson complaint described a "Kafkaesque journey through the debtors' prison network of Saint Louis County - a lawless and labyrinthine scheme of dungeon-like municipal facilities and perpetual debt." 47 The lawsuit prompted coverage of the new debtors' prisons by The New York Times, ${ }^{48}$ The Washington Post, ${ }^{49}$ The Atlantic, ${ }^{50}$ and National Public Radio. ${ }^{51}$ Academics, including historians, social scientists, and legal scholars, are starting to develop a growing literature on every aspect of this topic. ${ }^{52}$

${ }^{43}$ A Google Trends search for "debtors prison" showed a notable jump in the relative interest in the term around 2009. Other evidence for this proposition includes the sources cited supra, nn.1-9, and many others.

${ }^{44}$ Class Action Complaint, Fant v. City of Ferguson (Case No. 4:15-cv-00253)

[hereinafter Complaint, Fant $v$. Ferguson], available at http://equaljusticeunderlaw.org/wp/wp-content/uploads/2015/02/Complaint-FergusonDebtors-Prison-FILE-STAMPED.pdf. As of July, 2015, the case had survived a contentious motion to dismiss - the judge had initially dismissed, then reconsidered and then reinstated two allegations of unconstitutional imprisonment for debt - and was moving into discovery.

${ }^{45}$ Class Action Complaint, Jenkins v. City of Jennings (Case No. 4:15-cv-00252) [hereinafter Complaint, Jenkins $v$. Jennings], available at http://equaljusticeunderlaw.org/wp/wp-content/uploads/2015/02/Complaint-JenningsDebtors-Prisons-FILE-STAMPED.pdf.

46 See Complaint, Fant v. Ferguson, supra note 44, at 3 ("The City's modern debtors' prison scheme has been increasingly profitable to the City of Ferguson, earning it millions of dollars over the past several years. It has also devastated the City's poor, trapping them for years in a cycle of increased fees, debts, extortion, and cruel jailings.").

$47 \mathrm{Id}$. at 7.

48 Tina Rosenberg, Out of Debtors' Prison, With Law as the Key (Mar. 27, 2015 7:00 AM), http://opinionator.blogs.nytimes.com/2015/03/27/shutting-modern-debtorsprisons/?_r=0 ("Although the United States outlawed debtors' prison two centuries ago, that, in effect, is where Dawley kept going.").

${ }^{49}$ Spencer S. Hsu, Missouri Cities Sued Over Municipal Court Practices (Feb. 8, 2015), http://www.washingtonpost.com/local/crime/ferguson-and-jennings-mo-sued-over-

municipal-court-practices/2015/02/08/256da2d2-ae4f-11e4-abe8-

e1ef60ca26de_story.html.

50 Jessica Pishko, Locked up for Being Poor: How Private Debt Collectors Contribute to a Cycle of Jail, Unemployment, and Poverty (Feb. 25, 2015), http://www.theatlantic.com/national/archive/2015/02/locked-up-for-being-

poor/386069/.

${ }^{1}$ Civil Rights Attorneys Sue Ferguson Over 'Debtors Prisons (Feb. 8, 2015 9:03 PM), http://www.npr.org/blogs/codeswitch/2015/02/08/384332798/civil-rights-attorneys-sueferguson-over-debtors-prisons.

52 See, e.g., AleXes HARRIS, A Pound of Flesh (forthcoming 2015); Chrystin Ondersma, A Human Rights Framework for Debt Relief, 36 U. PA. J. INT'L L. 269 (2014); Gustav Peebles, Washing Away the Sins of Debt: The Nineteenth-Century 
Out of the mix of disturbing narratives and reports one can distill several common elements. The debts incurred all stem from criminal behavior, like shoplifting; or public offenses, like traffic violations, that are routed through the public legal system. The monetary obligations come under a mix of labels, including fines, fees, costs, and interest, and are generally either imposed at sentencing or as a condition of parole. An often-used umbrella term is Legal Financial Obligations (LFOs). ${ }^{53}$ Arrest warrants are sometimes issued when debtors fail to appear in court to account for their debts, but debtors report not receiving notice of summons or avoiding the courts out of an (understandable) fear of imprisonment. When courts have held the constitutionally required ability-to-pay hearings — and they've often neglected to do so $^{54}$ — such hearings have been extremely short, sometimes as brief as two minutes. Debtors are almost never provided with legal counsel.55 The total amount due fluctuates, sometimes wildly, and debtors are often unaware at any given point of the amount they need to pay to avoid incarceration or be released from prison. Some cities allow debtors to pay down their debts or secure extra necessities by performing janitorial work. ${ }^{56}$

Prison conditions are another troubling feature of the new system. Consider the following passage from the complaint against the city of Ferguson:

Once locked in the Ferguson jail, impoverished people owing debts to the City endure grotesque treatment. They are kept in overcrowded cells; they are denied toothbrushes, toothpaste, and soap; they are subjected to the constant stench of excrement and refuse in their congested cells; they are surrounded by walls smeared with mucus and blood; they are kept in the same clothes for days and weeks without access to laundry or clean underwear; they step on top of other inmates . . . in order to access a single shared toilet that the City does not clean; they develop untreated illnesses and infections in open wounds . . . ; they endure days and weeks without being allowed to use the

Eradication of the Debtors' Prison, 55 COMPaRative STUdIES IN SOC'Y \& History 701 (2013) (overviewing the prison reform movement in Europe and the United States and how it connected to capitalism); Erika Vause, Disciplining the Market: Debt Imprisonment, Public Credit, and the Construction of Commercial Personhood in Revolutionary France, 32 LAW \& HIS. REV. 647 (2014) (providing an account of debt imprisonment in revolutionary France).

${ }^{53}$ See, e.g., State v. Blazina, 344 P.3d 680, 683-84 (Wash. 2015).

54 See, e.g., Complaint, Jenkins v. Jennings, supra note 45 , at 43 ("The City prosecutor and City judge do not conduct indigence or ability-to-pay hearings. Regular observers of the City court have never once seen an indigence or ability to pay hearing conducted in the past decade.").

55 See, e.g., id. at 43.

56 This practice may violate the Thirteenth Amendment for prisoners not convicted of any crime. See Complaint, Jenkins $v$. Jennings, supra note 45, at 58. 


\section{DRAFT - DO NOT CITE OR CIRCULATE}

moldy shower; their filthy bodies huddle in cold temperatures with a single thin blanket . . . ; they are not given adequate hygiene products for menstruation; they are routinely denied vital medical care and prescription medication, even when their families beg to be allowed to bring medication to the jail; they are provided food so insufficient and lacking in nutrition that inmates lose significant amounts of weight; they suffer from dehydration out of fear of drinking foul smelling water ... ; and they must listen to the screams of other inmates languishing from unattended medical issues as they sit in their cells without access to books, legal materials, television, or natural light. Perhaps worst of all, they do not know when they will be allowed to leave. ${ }^{57}$

This selection is brief in light of the fifty-five-page complaint against Ferguson and the sixty-two-page complaint against Jennings. ${ }^{58}$ The experience of being caught in this system is so dehumanizing that two inmates in Jennings, unable to purchase their own release, hanged themselves in the jail. 59

And, like many aspects of the American criminal justice system, ${ }^{60}$ the new debtors' prisons are discriminatory on the axes of race and wealth. ${ }^{61}$ This result stems from both disproportionate poverty ${ }^{62}$ and

${ }^{57}$ Complaint, Fant v. Ferguson, supra note 44, at 2.

58 Among other things, the complaints alleged that debtors had been held for extended periods of time without toothpaste, soap, or a change of clothes, see Complaint, Fant v. Ferguson, supra note 44, at 9, that prisoners were not given feminine products for menstruation, see $i d$. at 10 , that their only drinking water came from an apparatus on top of the toilet, see id. at 13, that prison staff refused to allow a spouse to bring medication for a brain aneurism, see id. at 13-14, that walls were "moldy and covered in gum, paint chips, blood, mucus, and feces," see id. at 16, that prison staff denied medical treatment to a prisoner who developed boils "the size of eggs on his legs," that "flared and popped," filling his pants with blood and pus, see $i d$. at 19, that prisoners experienced a ratio or three or four men per bed, see id. at 24, that prisoners were not given sufficient coverings for the cold temperatures of the cell, see id. at 31, and that prisoners experienced sexual abuse and battery at the hands of jail staff, id. at 41 . As the complaint points out, such conditions would be unconstitutional under the Eighth Amendment even for convicted criminals. See id. at 46 .

59 See Complaint, Jenkins v. Jennings, supra note 45, at 46. The debt of one such individual was $\$ 500$. Id.

60 See, e.g., William J. Stuntz, The Collapse of American CRIMinal Justice (2011); Karakatsanis, supra note 3, at 254 ("There is a lot to say about American policing; it is, of course, tied up in big things that people don't like to talk about in polite company, such as structural racism . . . and capitalism - whose logic proudly depends on the perpetual reproduction of domination and control.").

61 See, e.g., Complaint, Fant v. Ferguson, supra note 44, at 33; see, e.g., id. at 36 ("These policies and practices have created a culture of fear among the City's poorest residents, who are afraid even to go to the City police department or the City court to explain their indigence because they know they will be jailed .... The same fear motivates many very many poor City residents to sacrifice food, clothing, utilities, sanitary home repairs, and other basic necessities of life in order to scrape together money to pay traffic debts to the City."). 
disproportionate policing 63 in communities of color - not only are such communities less able to pay debts owed to the state, but also aggressive enforcement patterns generate more such debts to begin with.

Even instances where defendants manage to scrounge up the money are morally and legally troubling, as the threat of imprisonment causes debtors to hand over money from disability and welfare checks, or induces family members and friends - who aren't legally responsible for the debt - to scrape together the money. ${ }^{64}$ This coercive, imprisonment-for-debt system seems ineluctably connected to the offender-funded model of criminal justice, especially when it interfaces with a growing trend toward privatization in the criminal system. Many of the debts are owed to for-profit prisons or probation companies like Judicial Correction Services (JCS), who wield the threat of imprisonment via contract with the state. Some of these public/private arrangements have recently been attacked in court as a form of racketeering. ${ }^{65}$

Of course, the modern debtors' prisons have not gone without criticism. In addition to the negative press, organizations like Equal Justice Under Law and the Southern Poverty Law Center have sued a handful of municipalities, ${ }^{66}$ and the American Civil Liberties Union

62 See, e.g., Poverty Rate by Race/Ethnicity (last visited July 10, 2015),http://kff.org/other/state-indicator/poverty-rate-by-raceethnicity/.

63 See, e.g., Natapoff, supra note 36, at 1065; Sonja Starr, Explaining Race Gaps in Policing: Normative and Empirical Challenges 4-7 (working paper) (Jan. 1, 2015), available

http://repository.law.umich.edu/cgi/viewcontent.cgi?article=1222\&context=law_econ_ current.

${ }^{64}$ E.g., Complaint, Fant v. Ferguson, supra note 44, at 36 ("From the perspective of City officials, these coercive threats are successful . . . . because [they] have been crucial to pressuring family members - who have no legal obligation to pay any money ... - to come up with money in order to get their loved ones released from jail.").

65 See Complaint, Reynolds v. Judicial Correction Services, Inc. (No. 2:15-cv-161MHT-CSC), available

http://www.splcenter.org/sites/default/files/downloads/case/1_-_complaint.pdf.

66 The two organizations teamed up to sue the city of Montgomery, Alabama, in 2013. See Amended Complaint, Cleveland v. Montgomery, No. 2:13-cv-732-MEF-TFM (M.D. Ala. Nov. 12, 2013), available at http://www.splcenter.org/sites/default/files/downloads/case/amended_complaint_harriet_cleveland_0.pdf. And in May 2014, Equal Justice Under Law brought another challenge. See First Amended Class Action Complaint, Mitchell v. City of Montgomery, No. 2:14-cv-186-MEF (M.D. Ala. May 23, 2014), available at http://equaljusticeunderlaw.org/wp/wp-content/uploads/2014/07/Complaint.pdf. Both lawsuits ended in settlements with the city. See Judicial Procedures of the Municipal Court of the City of Montgomery for Indigent Defendants and Nonpayment, 
has pursued an awareness campaign 67 in a number of states, sending letters to judges and mayors in Ohio ${ }^{68}$ and Colorado. ${ }^{69}$

Preliminary results have been encouraging. The city of Montgomery settled in 2014, agreeing to conduct the constitutionally required hearings, produce audial recordings, 70 provide Public Defenders, and adopt a "presumption of indigence" for defendants at or below $125 \%$ of the Federal Poverty Level. ${ }^{71}$ In Ohio, Chief Justice Maureen O'Connor took rapid action, issuing a bench card to clarify the procedures trial and municipal judges should take prior to imprisoning debtors for failure to pay. ${ }^{72}$ The Supreme Court of

Cleveland v. Montgomery, No. 2:13-cv-732-MHT-TFM (M.D. Ala. Sept. 12, 2014), available

http://www.splcenter.org/sites/default/files/downloads/case/exhibit_a_to_joint_settlem ent_agreement_-_judicial_procedures-_140912.pdf [hereinafter Judicial Procedures, Cleveland v. Montgomery]; Agreement to Settle Injunctive and Declaratory Relief Claims, Mitchell v. City of Montgomery, No. 2:14-cv-186-MHT-CSC (M.D. Ala. Nov. 17, 2014), available at http://equaljusticeunderlaw.org/wp/wpcontent/uploads/2014/07/Final-Settlement-Agreement.pdf [hereinafter Settlement Agreement, Mitchell v. Montgomery].

67 For an argument that such awareness campaigns are more effective than litigation, see Eric Balaban, Shining a Light into Dark Corners: A Practitioner's Guide to Successful Advocacy to Curb Debtor's Prisons, 15 LOY. J. PUB. INT. L. 275 (2014).

68 See Letter from Christine Link, Exec. Dir., ACLU of Ohio, et al., to Chief Justice Maureen O'Connor, Ohio Supreme Court (Apr. 2013), http://www.acluohio.org/wpcontent/uploads/2013/04/2013_0404LetterToOhioSupremeCourtChiefJustice.pdf.

69 See Recent Legislation, 128 HARV. L. REV. 1312, 1313 n.13 (2015). Between 2012 and 2013, the ACLU sent letters to Chief Justice Bender of the Colorado Supreme Court and three Colorado municipalities. See Letter from Mark Silverstein, Legal Dir., ACLU of Colo., and Rebecca T. Wallace, Staff Att'y, ACLU of Colo., to Chief Justice Michael Bender, Colo. Supreme Court, and Judge John Dailey, Chair, Criminal Procedure Comm. (Oct. 10, 2012), http://static.aclu-co.org/wpcontent/uploads/2013/12/2012-10-10-Bender-Dailey-Wallace.pdf; Letter from Rebecca T. Wallace, Staff Att'y, ACLU of Colo., and Mark Silverstein, Legal Dir., ACLU of Colo., to Herb Atchison, Mayor of Westminster (Dec. 16, 2013), http://static.acluco.org/wp-content/uploads/2014/02/2013-12-16-Atchison-ACLU.pdf; Letter from Rebecca T. Wallace, Staff Att'y, ACLU of Colo., and Mark Silverstein, Legal Dir., ACLU of Colo., to Joyce Downing, Mayor of Northglenn, and Woon Ki Lau, Northglenn City Prosecutor (Dec. 16, 2013); Letter from Rebecca T. Wallace, Staff Att'y, ACLU of Colo., and Mark Silverstein, Legal Dir., ACLU of Colo., to Joyce Jay, Mayor of Wheat Ridge (Dec. 16, 2013), http://static.aclu-co.org/wpcontent/uploads/2014/02/2013-12-16-Jay-ACLU.pdf.

70 See Settlement Agreement, Mitchell v. Montgomery, supra note 66, at 2-3.

${ }^{71}$ See Judicial Procedures, Cleveland v. Montgomery, supra note 66, at 1.

${ }^{72}$ See, e.g., Pierce J. Reed, Chief Justice Maureen O'Connor: A Legacy of Judicial Independence, 48 AKRON L. REV. 1, 8 (2015); Taylor Gillian, Jurist.org, Ohio Supreme Court Warns Judges to End "Debtors' Prisons," (Feb. 7, 2014), http://jurist.org/paperchase/2014/02/ohio-supreme-court-warns-judges-to-end-debtorsprisons.php; Office of Judicial Services, The Supreme Court of Ohio, Collection of 
Washington confirmed in March 2015 that the sentencing judge must make "an individualized inquiry into the defendant's current and future ability to pay before the court imposes LFOs." 73 And the Supreme Court of Missouri recently amended its rules to require municipal judges to push back deadlines or allow installment plans for debtors who couldn't pay court costs, fines, and fees. ${ }^{74}$

Legislatures have taken action, too: in 2014, the Colorado legislature almost unanimously passed a bill requiring courts to make ability-to-pay determinations on the record before imprisoning debtors for nonpayment of debt. ${ }^{75}$ And in 2015, the Georgia legislature passed House Bill 310 - again with few dissenters - which provides guidance for courts in indigency determinations. ${ }^{76}$

One might hope that this pushback will solve the problem. But there are many reasons to think there's a long road ahead. First, some of the legislative responses leave unresolved the substantive definition of indigence for the purposes of ability-to-pay hearings. ${ }^{77}$ Without that, discretion is left to the same courts and judges that have been imprisoning debtors thus far. ${ }^{78}$ Second, even tightly written laws, settlements, and resolutions need to be enforced, which requires accountability and monitoring. ${ }^{79}$ Abolishing the new debtors' prisons

Fines and Court Costs in Adult Trial Courts, available at https://www.supremecourt.ohio.gov/Publications/JCS/finesCourtCosts.pdf.

73 State v. Blazina, 344 P.3d 680, 685 (Wash. 2015).

${ }^{74}$ Order Dated December 23, 2014, re: Rule 37.65 Fines, Installment or Delayed Payments - Response to Nonpayment (Dec. 23, 2014), available at http://www.courts.mo.gov/sup/index.nsf/d45a7635d4bfdb8f8625662000632638/fe656f3 6d6b518a886257db80081d43c.

75 See Recent Legislation, supra note 69, at 1313, 1315.

76 See H.B. 310, 2015-2016 Reg. Sess. (Ga. 2015), available at http://www.legis.ga.gov/Legislation/en-US/display/20152016/HB/310; Gov. Nathan Deal, Office of the Gov., 2015 Bills Signed, http://gov.georgia.gov/bills-signed/2015 (last visited July 15, 2015). Among a host of other provisions, the law provides that courts shall

waive, modify, or convert [LFOs] . . . upon a determination by the court . . . that a defendant has a significant financial hardship or inability to pay or that there are any other extenuating factors which prohibit payment or collection; provided, however, that the imposition of sanctions for failure to pay such sums shall be within the discretion of the court through judicial process or hearings.

Id. at 25 .

77 See Recent Legislation, supra note 69, at 1316-19.

78 See id. at 1316 ("An exclusively procedural solution . . . runs the risk of leaving substantive discretion in the hands of the very judges who drew underinclusive lines to begin with.").

${ }^{79}$ See, e.g., Telephone Interview with Nathan Woodliff-Stanley, Exec. Dir., ACLU Colorado (Oct. 23, 2014) (on file with [Redacted] Law School library); Telephone 
is more a test of moral and societal conviction than of clever drafting. And finally (of course) some states haven't taken much action, if any, to address the issue, nor has it been raised in the federal courts within the last decade apart from the litigation discussed above.

Clearly what's happening has tremendous legal and moral import. Does it matter whether we call these new institutions "debtors' prisons" or not? Indeed it does. It matters because the label connects to the abolition of a historical practice, which left textual remnants in state constitutional and statutory texts across the nation. The analogy is invoked precisely because of its moral and legal relevance. The extent to which it holds as a legal matter may be relevant for litigation and legislation; and the extent to which it holds as a moral matter may be vital to our shared ethical life. ${ }^{80}$ It's to these questions that we now turn, beginning with a historical and doctrinal comparison of the contemporary and not-so-contemporary institutions.

\section{DebTors' Prisons, Old AND New}

\section{A. The Old Debtors' Prisons: Qualities and Function}

This Part turns the pages back to the old debtors' prisons. The literature already contains many good histories of debtors' prisons in America, ${ }^{81}$ but none of them span the complete range of our attention here, so it's worth laying out a basic historical account.

Interview with Alec Karakatsanis, Co-Founder, Equal Justice Under Law (Apr. 14, 2015) (on file with [Redacted] Law School library).

${ }^{80}$ For a recent exposition on the strengths of ethical analysis through the lens of shared ethical life, see Joshua Kleinfeld, Crime, Punishment, and Solidarity, 129 HARV. L. REV. _ (forthcoming 2016).

81 See, e.g., Peter J. Coleman, DebTors ANd CReditors in AMerica (1974); Edward J. BAlleisen, NAvigating Failure (2001) (focusing on the 1841 Bankruptcy Act); DAVID A. SkeEL, JR., DebT'S Dominion (2001). The classic history of bankruptcy is Charles WARREN, Bankruptcy In United States History (1935). The best recent treatment is by Harvard Law Professor BRUCE H. MANN, REPUBlic OF DeBToRS (2009). This short account cannot build on his excellent narrative, at least not until it cuts off at the repeal of the first national Bankruptcy Act in 1803 - before the state abolitions of debtors' prison. This ending point gives Mann's account a distinctly national feel. Indeed, he describes the "debate over debtor relief" as being "recast as a debate on the merits of bankruptcy." Id. at 191. This may be largely true, but the abolition of imprisonment for debt across the states seems to suggest that a state-level debate about attachment and execution law was ongoing as well. There are also good book-length treatments of imprisonment for debt in Europe. See, e.g., MARgot C. Finn, The Character of CREDit 109-196 (2003). 
Imprisonment for debt has a venerable legacy, a remnant of even harsher sanctions - like enslavement - that were imposed on defaulting debtors in the ancient world. ${ }^{82}$ British common law enabled private creditors to detain debtors to account for their debts prejudgment through body attachment, or the writ of capias ad respondendum (sometimes abbreviated as ca. resp. or ca. re.); and postjudgment through body execution, or the writ of capias ad satisfaciendum (ca. sa.). ${ }^{83}$ The American colonies largely preserved these writs. ${ }^{84}$ But the colonies had a bias against debtors' prison from the start: ${ }^{85}$ Georgia was even founded as a safe haven for debtors, ${ }^{86}$ and the young colonies advertised favorable provisions for debtors to entice newcomers. ${ }^{87}$ Yet as the colonies became more established and the industrial and commercial economies expanded, more and more creditors had an incentive to re-enforce the old writs, especially toward the end of the 1700 s and into the $1800 \mathrm{~s} .88$

Why imprison your debtor? Aside from sating vindictive feelings against someone thought to be deceptive, lazy, or irresponsible, ${ }^{89}$ the

82 The ancient Romans allowed debt slavery explicitly in the Twelve Tables (451-450 B.C.), as well as the dismemberment of the debtor unfortunate enough to have multiple vindictive creditors, see Note, Body Attachment and Body Execution: Forgotten but Not Gone, 17 WM. \& MARY L. REV. 543, 543 n.3, 544 n.4 (1976), although the latter sanction was probably not much used in practice, see Richard Ford, Imprisonment for Debt, 25 MicH. L. REV. 24, 24-25 (1926). The Hebrew Bible also contemplates a form of slavery for the repayment of debt, but cabins it through a familial right of redemption and strict temporal limits on the sale of property and people. See Exodus 21:1-11; Leviticus 25:8-55; Deuteronomy 15:1-18. The Christian New Testament alludes to the practice of imprisoning for nonpayment of debt in the parable of the unforgiving servant in Matthew's Gospel. See Matthew 18:21-25. Indeed, debt was associated with slavery to the ancient mind. See, e.g., Proverbs 22:7 (“[T] he borrower is the slave of the lender.") (NRSV).

${ }^{83}$ Black defines capias ad respondendum as "[a] writ commanding the sheriff to take the defendant into custody to ensure that the defendant will appear in court," and capias ad satisfaciendum as "[a] postjudgment writ commanding the sheriff to imprison the defendant until the judgment is satisfied." Capias, BLACK'S LAW DICTIONARY (10th ed. 2014). For a thorough history of early English law on this subject, see Note, supra note 82 , at $545-48$.

84 See Landrigan v. McElroy, 457 A.2d 1056, 1057-58 (R.I. 1983); Vogt, supra note 38, at 343. Detailed histories can be found in Note, supra note 82, at 543-50; and Note, Present Status of Execution Against the Body of the Judgment Debtor, 42 IowA L. REV. 306, 306-08 (1957).

85 See Seán McConville, Local Justice: The Jail, in The Oxford History of THE PRISON 297, 310 (Norval Morris \& David J. Rothman eds. 1995).

86 See Ford, supra note 82, at 28; COLEMAN, supra note 81, at 249.

${ }^{87}$ See Vogt, supra note 38 , at 343.

88 See id.; Coleman, supra note 81 , at 249. A similar effect was taking place in England at around the same time. See FINN, supra note 81, at 112.

89 See MANN, supra note 81, at 79. 
sanction was quite useful for inducing repayment in certain situations. A creditor might suspect the debtor had hidden assets and wielded imprisonment to cause the debtor to fess up. ${ }^{90}$ Moreover, certain kinds of property were statutorily exempt from attachment.91 The threat of imprisonment could induce a debtor to turn over exempt property voluntarily, property that the creditor couldn't otherwise reach. A more troubling subset of this scenario concerns the assets of family and friends: absent imprisonment, even close relations would hardly be likely to proffer funds; with incarceration on the creditor's menu of sanctions, some of them might dig deep into their pockets. ${ }^{92}$ In brief, debtors' prisons existed because they worked. While most imprisoned debtors simply couldn't pay, ${ }^{93}$ for many creditors, putting their debtors through the crucible was worth the cost.

What were the prisons like? In both Britain and the postRevolutionary United States, ${ }^{94}$ debtors were typically held in separate institutions, or separate wings of a common jail. The two most prominent institutions in America were New York's New Gaol and Philadelphia's Prune Street jail.95 Thus, unlike today, debtors were surrounded by other prisoners held for more or less the same offense, and they had the cognitive benefit of differentiating themselves from the "criminals" in the common jails. Harvard Law Professor Bruce Mann documents how the debtors in one prison formed a parliamentary society, complete with regulations, trials, and due process. ${ }^{96}$ Visitors "came and went with relative ease," 97 and in some cases families may have moved in with the incarcerated patriarch. ${ }^{98}$

Debtors' prisons held people from a range of socioeconomic classes, but the bulk of the inmates were poor. ${ }^{99}$ Even where debtors could take a "poor man's oath" after some months of imprisonment, swearing that they had no assets with which to pay, and be released, they had to wait, usually thirty days, to qualify for those laws. ${ }^{100}$ Debtors with accounts over a certain level — lines of credit only available to the

\footnotetext{
90 See id.

91 See id.

92 See id.

93 See id.

94 Mann notes that, prior to the Revolution, there were no debtors' prisons, "[s]trictly speaking," in the country. Id. at 85 .

${ }_{95} \mathrm{Id}$. at 85.

96 See id. at $147-52$.

${ }^{97} \mathrm{Id}$. at 90 .

${ }^{98} \mathrm{Id}$. at $91-92$.

99 See Coleman, supra note 81, at 254.

100 See Coleman, supra note 81, at 254.
} 
middle class and up - were not eligible to take the oath. ${ }^{101}$ But the very rich could evade capture by remaining within the confines of their locked houses, where they were immune from service of process. They "kept close," as the saying went. 102 Financier Robert Morris, once the wealthiest man in America, evaded arrest for seven months by hiding out in "Castle Defiance," his home outside Philadelphia. ${ }^{103}$

The debtors' prisons were racially homogenous, though: the American middle class was still predominantly white, and a free black man at risk of defaulting on a line of credit had more serious problems on his mind. There were women in the debtors' prisons, but it's hard to know how many were imprisoned as debtors - it was more common to see prostitutes or wives living with their imprisoned husbands. ${ }^{104}$

Conditions were dismal, at least for some.105 Upper-class debtors were housed perhaps four or five to a room. ${ }^{106}$ Debtors of a lower class lived in far more cramped quarters, slept in the hallway, or were relegated to a basement cell. ${ }^{107}$ Debtors had to provide their own food (if they had the means), ${ }^{108}$ and the living space was cramped and foul, 109 described as a "human slaughter house" and a "dismal cage." 110 Prisoners faced starvation, violence, and disease, ${ }^{111}$ including the alarming bouts of yellow fever that swept through the cities.112 The extremely wealthy, like Morris, were able to rent their own room, bring

\footnotetext{
101 See MANN, supra note 81, at 50, 101.

102 See MANN, supra note 81, at 26-27 (noting that "keeping close" was "an option available only to debtors with the financial resources to sustain it," id. at 26).

${ }^{103} I d$. at 28. Morris treated the engagement as a "game of cat and mouse." Id. For example, Mann recounts how, when he had to let in a worker to repair his windows, he "went out on the widow's walk atop his roof, locking the door behind him in case the man had been deputized to serve writs." Id. On Sunday, writs could not be served, so Sunday became the only day debtors were free to walk about, and even then with some trepidation. Id.

${ }^{104} I d$. at $91-92$.

105 As Coleman points out, "[r]eformers used such examples to create the impression that these conditions were typical rather than exceptional. They were not." COLEMAN, supra note 81 , at 254.

106 MANN, supra note 81 , at 87.

$107 \mathrm{Id}$.

$108 I d$.

109 See ColEman, supra note 81, at 254 ("[I]nevitably there were instances of the grossest inhumanity - nursing mothers deprived of their liberty, aged Revolutionary veterans jailed for trifling amounts, prisoners crowded into tiny, foul cells, and cases of exploitation, brutality, and death.").

110 MANN, supra note 81 , at 87.

$111 \mathrm{Id}$. at 88.

$112 I d$. at 97.
} 
in furniture like a desk and chairs, and even redecorate. ${ }^{113}$ Such debtors guarded their living space jealously. In fact, in Mann's "republic of debtors," managing the housing and roommate market within the debtors' prison was of paramount concern. ${ }^{114}$

America did see some early reforms to the debtors' prison system. For example, a New Hampshire law passed in 1771 enabled debt prisoners to roam the prison yard and up to one hundred feet without it. 115 South Carolina allowed certain debts to be paid by installment.116 But a swell of incarcerated debtors during the growth of commercial economy - including some blockbuster market crashes that landed some of the most wealthy Americans in debtors' prison - led to a growing public sentiment against the institutions. ${ }^{117}$ States began to cabin their reach (by excluding certain classes of debtors, like women and Revolutionary War veterans) and widen the scope of the confinement - some of them out to the state borders. ${ }^{118}$ After Massachusetts banned the imprisonment of petty debtors in 1811, a growing movement began to see its way clear to complete abolition. ${ }^{119}$

\section{B. The Abolition Movement: Purpose and Limits}

The abolition movement began in the 1750 s and 1760 s, when pamphlets criticizing the practice began to appear. ${ }^{120}$ The early literature pointed out the inefficiencies of jailing merchants and skilled tradesmen for events beyond their control. ${ }^{121}$ By the 1780s, voluntary societies for the relief of debtors were being organized. ${ }^{122}$ In 1800, lawyer William Keteltas, himself in debtors' prison, began publishing a newspaper called Forlorn Hope, ${ }^{123}$ which denounced the criminal treatment of debtors, characterizing it as a "lingering death." 124 The emblem of his newspaper demonstrates themes that would resound throughout the growing movement:

[A] black slave clad only in a loincloth, on bended knee, with his hands clasped together and his head tilted upward in an attitude of supplication, chained by the wrists to a white man dressed in a tattered shirt and worn

\footnotetext{
113 Id. at 100.

114 See id. at 154.

115 See Note, supra note 82, at 548-49.

116 See id. at 549.

117 See MANN, supra note 81, at 102.

118 Note, supra note 82, at 549-50; COLEMAN, supra note 81, at 257.

119 See COLEMAN, supra note 81, at 256.

120 MANN, supra note 81 , at 81 .

121 Id. at 84 .

122 Id. at 89.

$123 \mathrm{Id}$. at 103 .

124 Id. at 104 .
} 
breeches, standing with his head bowed and his hands chained at his waist. Above them curled a banner with the words, "We should starve were it not for the Humane Society." Below them wrapped another banner with the defiant slogan, "Liberty Suspended But Will Be Restored."125

The stock-broker and state legislator John Pintard, also in debtors' prison, also made explicit the connection between imprisonment for debt and slavery. ${ }^{126}$ While Keteltas clearly meant to condemn both practices, other writers simply (and less progressively) urged that society not treat debtors as badly as slaves. ${ }^{127}$

Over time, a national debate became focused on the propriety of a national bankruptcy statute, ${ }^{128}$ lighting up a constitutional provision that had been largely skimmed over at the Constitutional Convention. 129 But as the federal government tinkered with bankruptcy, ${ }^{130}$ states began working on their own protections for debtors. In 1821, Kentucky, led by Colonel Richard M. Johnson, became the first state to abolish debtors' prisons. ${ }^{131}$ Ohio and Illinois were next. ${ }^{132}$ Many other states followed suit in the 1830 s and 1840 s, ${ }^{133}$ and by the 1870 s the practice was discontinued by almost all of the states. ${ }^{134}$

Contrary to the oft-repeated (and unsubstantiated) claim, ${ }^{135}$ the federal government has never abolished debtors' prisons across the

\footnotetext{
125 Id. at 110.

126 Id. at 126.

${ }^{127} I d$. at $144-45$.

128 See id. at 191.

129 Id. at 182 .

130 Even though multiple bills were proposed through the 1790s, Congress only managed to pass a temporary bankruptcy bill in 1800. See id. at 187.

131 See Leland Winfield Meyer, The Life and Times of Colonel Richard M. JOHNSON OF KENTUCKY 263 (1932). Johnson, who would later become Van Buren's vide president, has been described as "the prime mover toward getting the federal government to legislate against the imprisonment of persons for debt); see id. at 28289; see also Henry Burnett, Chancery Jurisdiction in Kentucky in Cases of Fraudulent Conveyance, 1 KY. L.J. LoUISVILLE 368, 371 (1881-1882).

132 See MEYER, supra note 131, at 287.

${ }^{133}$ See Charles Jordan Tabb, The History of the Bankruptcy Laws in the United States, 3 AM. BANKR. INST. L. REV. 5, 16 (1995).

134 See Note, supra note 82, at 550; ColEMAN, supra note 81, at 257.

135 There are various conflicting accounts available of when debtors' prisons were "abolished" in this way, with dates in print including 1832, 1833, 1839, and 1896. Several online sources have repeated 1833. E.g., BANNON, supra note 26, at 19; Jennings, supra note 131. These sources seem to trace back to a law review article that asserted the proposition without any support. Tabb, supra note 133, at 16 . Warren's account, though, had pointed to the 1839 federal statute, see WARREN, supra note 81 , at 52 , and in a footnote gave some statistics from 1833 , which may have caused the confusion, see id. at 52 n.8. Another source has 1832. End of Debt
} 
United States. In 1832, again due to the efforts of Colonel Johnson, Congress did abolish imprisonment for debt in the District of Columbia and the territories. ${ }^{136}$ And beginning at the end of the eighteenth century, it passed a series of Conformity Acts, extending the same protections to debtors in federal court as they would have enjoyed in the state court where the federal court sat.137 In 1792, the Second Congress passed an act giving debtors the same "privileges of the yards or limits of the respective gaols" and establishing safety valves for debtors with estates worth less than $\$ 20$ and those whose creditors failed to pay their prison bills. ${ }^{138}$ That law had a sunset provision, ${ }^{139}$ so in 1800, Congress passed a bill doing roughly the same thing, for the long haul. ${ }^{140}$ Then, in 1839, after a number of states had banned imprisonment for debt, Congress passed a law providing that federal courts would follow the rules of the states in which they sat. ${ }^{141}$ That

Prison, U.S. Census Bureau (Dec. 11, 2014), http://www.prnewswire.com/newsreleases/us-census-bureau-daily-feature-for-december-11-300008038.html. Another source misdated the original passing of the federal statute to 1896. See Richard E. James, Putting Fear Back into the Law and Debtors Back into Prison: Reforming the Debtors' Prison System, 42 WASHBURN L.J. 143, 154 (2002).

136 See H.R. REP. No. 22-5, at 1-13 (1832); see also MEYER, supra note 131, at 289. The bill read as follows:

[I]t shall not be lawful for any of the courts of the United States to issue a capias ad satisfaciendum, or any other process, by which the body may be subject to arrest or imprisonment, upon any judgment at law or final decree in chancery, for payment of money founded upon any contract, express or implied, which may have been entered into, or upon cause of action, which may have accrued after the fourth day of July next; and upon all such contracts and causes of action after judgment, imprisonment shall be totally and absolutely abolished.

H.R. REP. NO. 22-5, at 12 (1832).

137 These Conformity Acts were precursors to Erie R.R. Co. v. Thompkins, 304 U.S. 64 (1938).

1382 Cong. Ch. 29, May 5, 1792, 1 Stat. 265 (1792). The act was entitled, "An Act for the relief of persons imprisoned for Debt."

139 See id. $\S 4$ ("That this act shall continue and be in force, for the space of one year from the passing thereof, and from thence to the end of the next session of Congress, and no longer.").

1406 Cong. Ch. 4, Jan. 6, 1800, 2 Stat. 4 (1800). This act bore the same name as its predecessor.

14125 Cong. Ch. 35, Feb. 28, 1839, 5 Stat. 321 (1839). The act was entitled, "An Act to abolish imprisonment for debt in certain cases," and read as follows: "[N]o person shall be imprisoned for debt in any State, on process issuing out of a court of the United States, where by the laws of such State, imprisonment for debt has been abolished; and where by the laws of a State, imprisonment for debt shall be allowed, under certain conditions and restrictions, the same conditions and restrictions shall be applicable to the process issuing out of the courts of the United States; and the same proceedings shall be had therein as are adopted in the courts of such State."). Id. The law had to be clarified in 1841. It seems the former law left available to creative litigants the interpretation that the abolition only referred to states where 
law remains on the books today. ${ }^{142}$ However, it's also clear that, early on, federal courts exempted from the scope of the Conformity Act legal actions in which the United States was the creditor. ${ }^{143}$

Moreover, during the same century, the federal government would begin (in fits and starts) to blanket the states with uniform debtor relief under the Bankruptcy Clause of the U.S. Constitution. ${ }^{144}$ A bankruptcy statute generally enables debtors, after jumping through various hoops (usually including turning over control of their assets to their creditors), to receive a discharge of the remaining debt, which permanently bars the creditor from taking legal action to collect it, including body attachment or arrest. The first United States bankruptcy act was passed in 1800 (following the Panic of 1797), but was repealed in 1803.145 Other attempts went into force from 18411843 (following the Panic of 1837) ${ }^{146}$ and from 1867-1878 (following the Panic of 1857 and the Civil War). ${ }^{147}$ Permanent bankruptcy legislation was passed in 1898 (following the Panic of 1893). ${ }^{148}$ Thus some Americans enjoyed limited respite from debtors' prison under the federal bankruptcy statutes during three brief intervals from 18001898 and thereafter under the permanent federal bankruptcy statute.

debtors' prisons had been abolished as of the time of the passage of the law. The 1841 act clarified that that statute should be construed to abolish debtors' prison wherever a state had abolished it, even if the abolition took place in the future. See 26 Cong. Ch. 2, Jan. 14, 1841, 5 Stat. 410 (1841) ("[T] he act ... shall be so construed as to abolish imprisonment for debt . . . in all cases whatever, where, by the laws of the State in which the said court shall be held, imprisonment for debt has been, or shall hereafter be, abolished") (emphasis added).

142 See 28 U.S.C. $\S 2007$ (2012) (originally passed in 1948).

143 See United States v. Hewes, 26 F.Cas 297 (E.D. Pa. 1840).

${ }^{144}$ U.S. ConsT. art. I, § 8, cl. 4 ("The Congress shall have Power . . To establish . . . uniform Laws on the subject of Bankruptcies throughout the United States."). Professor David Skeel points out that part of the reason for the failure of the early Bankruptcy Acts is that they were administered through the federal district courts. See SKEEL, supra note 81, at 27.

145 See Tabb, supra note 133, at 13-14; see also Bankruptcy Act of 1800, ch. 19, 2 Stat. 19, repealed by Act of Dec. 19, 1803, ch. 6, 2 Stat. 248.

146 See Tabb, supra note 133, at 13-14; see also Bankruptcy Act of 1841, ch. 9, 5 Stat. 440, repealed by Act of Mar. 3, 1843, ch. 82, 5 Stat. 614.

147 See Tabb, supra note 133, at 13-14; see also Bankruptcy Act of 1867, ch. 176, 14 Stat. 517, repealed by Act of June 7, 1878, ch. 160, 20 Stat. 99.

148 See Tabb, supra note 133, at 13-14. The 1898 Act was amended in 1938 by the Chandler Act, Ch. 575, 52 Stat. 840 (repealed 1978). The most recent major reforms are the Bankruptcy Reform Act of 1978, Pub. L. No. 95-598, 92 Stat. 2549, and the Bankruptcy Abuse and Consumer Protection Act of 2005, Pub. L. 109-9, Apr. 20, 2005, 119 Stat. 23 (codified as amended in scattered sections of 11, 12, 18, and 28 U.S.C.). 
Eventually, the ban on imprisonment for debt would produce fortyone state constitutional provisions. ${ }^{149}$ Some of the provisions read as flat bans ("There shall be no imprisonment for debt"); 150 others have various carve-outs and exceptions in the text. ${ }^{151}$ But subsequent caselaw narrows the practical differences between them, by reading into the flat bans largely the same carve-outs. ${ }^{152}$ Interestingly, the current language isn't necessarily the original form: some of the bans were modified over time. ${ }^{153}$ The nine states that haven't constitutionalized a ban on imprisonment for debt - Connecticut,

149 The string-cites available in the legal literature, Vogt, supra note 38, at 335 n.9; Michael M. Conway, Note, Imprisonment for Debt: in the Military Tradition, 80 YALE L.J. 1679, 1679 n.1 (1971); Note, supra note 82, at 550 n.45, are outdated in places, so an accurate and updated set of citations is called for. The constitutional imprisonment-for-debt provisions are as follows: ALA. Const. art. I, § 20; ALAS. Const. art. I, § 17; ARIZ. Const. art. II, § 18; ARK. Const. art. II, § 16; CAL. Const. art. I, § 10; Colo. Const. art. II, § 12; Fla. Const. art. 1, § 11; GA. Const. art. I, § 1, I XXIII; HAWAII Const. art. I, § 19; IDAHO Const. art. I, § 15; IND. Const. art. I, § 22; Iowa Const. art. I, $\S 19$; KAn. Const. BILl of Rights, $\S 16$; Ky. Const. BILL OF Rights, § 18; MD. Const. art. III, § 38, Mich. Const. art. I, § 21; Minn. Const. art. I, $\S 12$; Miss. Const. art. III, § 30; Mo. Const. art. I, § 11; Mont. Const. art. II, § 27; NEB. Const. art. I, § 20; NeV. Const. art. I, § 14; N.J. ConsT. art. I, I 13; N.M. Const. art. II, § 21; N.C. Const. art. I, § 28; N.D. Const. art. I, § 15; OHIO ConsT. art. I, § 15; OKLA. Const. art. II, § 13; ORE. Const. art. I, § 19; PA. Const. art. I, § 16; R.I. Const. art. I, § 11; S.C. Const. art. IV, § 24; S.D. Const. art. IV, § 15; TEnN. Const. art. I, § 18; TEX. Const. art. I, § 18; UTAH Const. art. I, § 16; VT. Const. ch. II, § 40; WASH. Const. art. I, § 17; WIS. Const. art. I, § 16; WYo. Const. art. I, § 5.

150 See, e.g., ALA. ConsT. art. I, § 20 ("That no person shall be imprisoned for debt"); GA. Const. art. I, § 1, ๆ XXIII ("There shall be no imprisonment for debt"); TEX. ConsT. art. I, § 18 ("No person shall ever be imprisoned for debt") (emphasis added).

151 See, e.g., Colo. Const. art. II, § 12 ("No person shall be imprisoned for debt, unless upon refusal to deliver up his estate for the benefit of his creditors in such manner as shall be prescribed by law, or in cases of tort or where there is a strong presumption of fraud."); MD. CONST. art. III, $\S 38$ ("No person shall be imprisoned for debt, but a valid decree of a court of competent jurisdiction or agreement approved by decree of said court for the support of a spouse or dependent children, or for the support of an illegitimate child or children, or for alimony (either common law or as defined by statute), shall not constitute a debt within the meaning of this section.").

152 As the Supreme Judicial Court of Massachusetts said, "Even the significant word 'abolished,' when taken, as it must be, in connection with the other detailed provisions of the act, is found to mean only that imprisonment for debt, from the time it went into operation, should be regulated, modified, and mitigated in conformity with these provisions." Appleton v. Hopkins, 71 Mass. (5 Gray) 530, 532-33 (1855).

${ }^{153}$ In State v. Higgins, 326 S.E.2d 728 (Ga. 1985), the Georgia Supreme Court described the transformation of its constitutional ban of debt, which began in 1798 with a carve-out for fraud and delivery of estate. See id. at 728. The Georgia Constitution of 1861 removed the fraud carve-out. Id. The Constitution of 1865 clarified that the delivery-of-estate provision only referred to nonexempt assets. Id. at 728-29. Finally, in 1868, the text was again changed, this time to read, "There shall be no imprisonment for debt," a formulation that survived into the constitutions of $1877,1945,1976$, and 1983. Id. at 729 . 
Delaware, Louisiana, Maine, Massachusetts, New Hampshire, New York, Virginia, and West Virginia - all took statutory action. ${ }^{154}$ Some statutes looked a lot like the constitutional bans, ${ }^{155}$ some explicitly abolished the writ of capias ad satisfaciendum, ${ }^{156}$ and others simply reinvigorated procedural protections for debtors who genuinely couldn't pay. ${ }^{157}$

The difference between states with constitutional provisions and statutory provisions can easily be overstated. First, many states began with statutes and later constitutionalized, 158 probably mostly to remove the question from fickle legislatures. ${ }^{159}$ Not having a

154 It's interesting to note that, with the exception of Louisiana, all of these states were of the original thirteen colonies - and that there's a clear geographical center in New England.

155 In 1855, Massachusetts passed a statute saying, "imprisonment for debt is hereby forever abolished in Massachusetts." Appleton v. Hopkins, 71 Mass. (5 Gray) 530, 532 (Mass. 1855). The statute was also meant to punish fraudulent debtors. See id. at 533. In 1831, Maine passed a statute entitled the "abolition of imprisonment for honest debtors," and another in 1835 that strengthened the escape valve for poor debtors. See Codman v. Lowell, 3 Me. (3 Greenl.) 52, 57 (1824) ("It is evidence that a great change has taken place in public opinion on the subject of imprisonment for debt. . . In proof of this, we might mention among other things, the recent statute of this State in relation to imprisonment for debt on execution."); Gooch v. Stephenson, 15 Me. (3 Shep.) 129, 130 (Me. 1838).

156 E.g., W. VA. CODE § 56-3-2 ("The ... writ of capias ad satisfaciendum [is] abolished and shall not hereafter be issued.") (1849); CODE OF VA. $§ 8.01-467$ ("No . . . writ of capias ad satisfaciendum . . . shall be issued hereafter.") (1849).

157 E.g., ME. REV. STAT. § 3605 (all provisions for arrests repealed in 1971); ANN. L. MASS. c. $224 \S 6$ (repealing arrest on execution unless creditor can show through specified procedures that the debtor intends to leave the commonwealth); N.Y. DEBTOR AND CREDITOR LAW §§ 120-132; N.H. REV. STAT. 568.

158 States who initially banned imprisonment for debt via statute and later constitutionalized that value include New Jersey, see Note, Civil Arrest of Fraudulent Debtors: Toward Limiting the Capias Process, 26 RUTGERS L. REV. 853, 855 n.19 (1972), South Carolina, see Lowden v. Moses, 14 S.C.L. (3 McCord) 93 (S.C. Ct. App. 1825), and Ohio, see Parker v. Sterling, 10 Ohio 357, 358 (Ohio 1841).

${ }^{159}$ For example, the South Carolina legislature apparently banned imprisonment for debt in 1815, but then brought it back in 1823. See Lowden, 14 S.C.L. at 101. An alternative concern was whether banning imprisonment for debt ran up against the Contract Clause of the federal constitution. See, e.g., MEYER, supra note 131, at 235 (describing Johnson's concern that the 1821 Kentucky ban would be struck down on these grounds). This issue had been addressed by the Supreme Court just before most states began banning imprisonment for debt. The Contract Clause in the federal Constitution, see U.S. ConsT. art. I, § 10, cl. 1 ("No State shall . . pass any . . . Law impairing the Obligation of Contracts ...."), was held around this time not to be a ban on state abolition of imprisonment for debt. See Sturges v. Crowninshield, 17 U.S. (4 Wheat.) 122 (1819); Ogden v. Saunders, 25 U.S. 213 (1827); Mason v. Haile, 25 U.S. (12 Wheat.) 370 (1827). States generally did not develop separate contract clause jurisprudence under their own constitutions. See, e.g., Lowden, 14 S.C.L. at 101; Wood v. Malin, 10 N.J.L. 208, 209 (N.J. 1828). 
constitutional provision might mean simply that the state legislature maintained its conviction. 160 Second, debtors do not necessarily get better treatment in a state with a constitutional, as opposed to statutory, ban - again due to subsequent caselaw.

\section{Functional Reasons for the Ban}

There were (and are) good reasons to ban debtors' prisons. Laying these reasons out here is important, as imprisonment for debt, it seems, once made sense. Indeed, one can imagine various scenarios under which private parties, for instance, would agree to body attachment in a debt contract as a commitment mechanism. The functional reasons for the ban (and the fairly rapid change in public opinion) have been well rehearsed in the literature, but it's worth reiterating here the major themes. The first explanation seems the most plausible driver of the change, while the second and third explanations help explain the speed with which it took place - and how it became a socio-cultural change in addition to a legal one:

Theme No. 1: imprisonment for debt lost its appeal as a coercive sanction against rapidly improving alternatives, for both creditors and debtors. As historian Peter Coleman put it, "the debtors' prison disappeared because it was obsolete." 161 In colonial America, information about assets available to secure or pay off a debt was not reliable, and debtors or potential debtors couldn't easily signal their willingness and ability to pay ex ante. ${ }^{162}$ The corporate form hadn't truly taken off, making it difficult to sell equity in commercial enterprises. And the welfare state hadn't come into existence to provide social insurance for those seeking subsistence credit. With the rise of the corporation and secured credit (including the chattel mortgage, the promissory note, and the crop-lien system), most entrepreneurial endeavors of any merit could find funding. ${ }^{163}$ In fact,

\footnotetext{
160 See, e.g., Makarov v. Commonwealth, 228 S.E.2d 573, 575 (1976) (“[T]here is no explicit proscription in Virginia's Constitution against imprisonment for debt. But it is nevertheless established in this State that a person may not be imprisoned, absent fraud, for mere failure to pay a debt arising from contract or for mere failure to pay a judgment for a debt founded on contract.").

161 COLEMAN, supra note 81, at 268.

162 See, e.g., MANN, supra note 81, at 7 ("Before Dun \& Bradstreet pioneered centralized credit reporting in the nineteenth century, the decision to extend or withhold credit rested on person ties or experience, or, absent those, on second- or third-hand information ..."); COLEMAN, supra note 81, at 250.

163 See ColEman, supra note 81, at 260-65 ("[L]oans became written, enforceable contracts subject to the law of commercial instruments. The debtors' prison had no more place in this world of lending and borrowing than it had had in the older world of mutual trust and understanding." Id. at 261); Vogt, supra note 38, at 345-46.
} 
under such conditions, it makes sense to have a ban on imprisonment for debt. Without a flat ban, entrepreneurs might signal their creditworthiness by signing off on imprisonments clauses excessively, defeating the shift to more cost-effective signals. ${ }^{164}$ And the sanction of imprisonment for debt would send debtors and their families into the arms of charity, ${ }^{165}$ driving up public costs for private gain. Better to make the right nondisclaimable: any increase in the cost of credit, on this view, is worth it as a form of social insurance.

Theme No. 2: society began to view itself as evolving from a regressive, punitive society to a progressive society focused on efficiency. ${ }^{166}$ The prison, once marketed as an opportunity for reflection and repentance, came to be seen as a haven of luxury and rest - not the best training ground for failed capitalist workers. A system that punished debt with incarceration felt inefficient, compared to a model that encouraged thrift and hard work. Under modern, commercial conditions, the opportunity cost of imprisoning otherwise capable workers seemed far too high, 167 especially as the perceived benefits of imprisonment dropped sharply.

Theme No. 3: Nonpayment of private debt - and breach of contract more generally - underwent a shift from sounding in sin to sounding in risk. ${ }^{168}$ As modern commercial life picked up steam (quite literally), expectations about one's financial future necessarily became more probabilistic: agrarian finance is, to a large extent, more predictable

164 See Samuel A. Rea, Jr., Arm-Breaking, Consumer Credit, and Personal Bankruptcy, 22 ECON. INQUIRY 188 (1984).

165 See, e.g., Note, supra note 82, at 548 ("[The] families [of incarcerated debtors] often became dependent on charity.”). One might be particularly concerned about this outcome from a behavioral law-and-economics perspective on individual action. See Russell Korobkin, A "Traditional" and "Behavioral" Law-and-Economics Analysis of Williams v. Walker-Thomas Furniture Company, 26 U. HAW. L. REV. 441 (2004).

166 See Peebles, supra note 52.

167 See, e.g., Note, supra note 82, at 547-48 (pointing out the "irony" of imprisoning debtors whose chief concern is raising money to pay back their creditors and noting that the "demand for manpower [in the American colonies] to build and protect the new communities ... made debtors' prison an impractical institution."); Vogt, supra note 38 , at 345 ; Mann, supra note 81 , at 58 .

168 This theme has been emphasized by both Bruce Mann and anthropologist Gustav Peebles. For example, Mann discusses Samuel Moody, a "creditors' minister," MANN, supra note 81 , at 36 , who preached that "Debts must be paid, tho' all go for it," and "to lie in Debt, is a Sin," id. at 38. But his sermons came "at a time of contest in the economic culture of New England." $I d$. at 43. A new critique was made possible by the "redefinition of debt from moral delict to economic risk." Id. at 82. See also Gustav Peebles, supra note 52. 
than commercial finance. 169 Under these conditions, the sin or crime label — with all the sanctions normally associated with it - for nonpayment of debt came to be viewed as culturally inappropriate: too punitive, not nuanced enough. Importantly, since this shift took place in the register of cultural values, and not legal texts, mores were able to swing fairly rapidly, helping explain the tectonic shift in the legal landscape. Imprisonment for debt came to be viewed as unfair, especially given the externalities it imposed upon families and the community. ${ }^{170}$ Behavior worth imprisonment could always be reframed in criminal law, and it was.

\section{Doctrinal Limits on the Ban}

The literature has long recognized that the "abolition" of debtors' prison was tightly contained in scope. One author, writing in 1889, examined state constitutional provisions banning imprisonment for debt and pointed out a number of ways in which these provisions were limited. ${ }^{171}$ Over one hundred years later, another author identified the same basic legal categories as exceptions under the constitutional provisions ${ }^{172}$ and concluded there's a de facto debtors' prison system in the United States. ${ }^{173}$

The doctrinal limits on the ban cabined it along two dimensions: First, debtors evading payment were sculpted out from the bans. For instance, a number of constitutional provisions contained (or had read in) an exception for fraud. ${ }^{174}$ The fraud exception has been interpreted to allow courts to order a defendant believed to have money to pay. ${ }^{175}$

\footnotetext{
169 See MANN, supra note 81, at 35, 56 (quoting Benjamin Franklin); BalleISEN, supra note 81 , at 26-48 (describing the interwoven structure and commercial risks of the developing economy).

170 See, e.g., Coleman, supra note 81 , at 250.

171 See J. C. Thomson, Imprisonment for Debt in the United States, 1 JURID. REV. 357 (1889).

172 See James, supra note 135, at 149-54 (discussing civil contempt); id. at 155-56 (discussing child support payments); $i d$. at 156-57 (discussing taxes, that is, debts owed to the United States government).

173 See id. at 149. Other authors have noted this as well. See, e.g., Note, supra note 82 , at $550-55$.

${ }^{174}$ For constitutional provisions, see, for example, ARIZ. Const. art. II, § 18; ARK. Const. art. II, § 16; IDAHO CONST. art. I, § 15. For caselaw, see, for example, Towsend v. State, 124 Ga. 69 (1905) ("[I]n enacting the statute now under consideration, the Legislative purpose was not to punish one simply for a failure to pay a debt, but was to punish the act of securing the money or property of another with a fraudulent intent .....); Appleton v. Hopkins, 71 Mass. (5 Gray) 530, 533 (1855) (noting that a major purpose of the statute was "to punish fraudulent debtors"); Towsend v. State, 52 S.E. 294, 294 (Ga. 1905).

175 See James, supra note 135, at 359.
} 
In some cases, even leaving the state in a furtive manner would count as fraud. ${ }^{176}$ And if a court ordered a party to turn over specific assets, that party's refusal to comply would give rise to the jailable offense of civil contempt of court without offending the constitutional bans. ${ }^{177}$

Second, courts held a long list of monetary obligations not to count as "debts" under the ban. Some constitutional provisions limited the ban to debts arising out of contract, as opposed to tort or crime. ${ }^{178}$ Similarly, failure to pay child support or alimony could give rise to arrest and incarceration. 179 So too with criminal costs and fines, ${ }^{180}$ although courts made clear the legislature couldn't criminalize the mere nonpayment of commercial debt as a constitutional workaround. ${ }^{181}$ Thus, while debtors' prisons were abolished step-bystep with regard to commercial debts, they have never been abolished with regard to noncommercial debts, including debts stemming from tort, ${ }^{182}$ crime, ${ }^{183}$ tax and licensing fees, ${ }^{184}$ child support, ${ }^{185}$ and alimony. ${ }^{186}$ Under bankruptcy law as well, some debts cannot

\footnotetext{
176 See id.

177 See, e.g., Boarman v. Boarman, 556 S.E. 2d 800, 804 (W. Va. 2001); Samuel v. Dodd, 142 F. 68, 70 (5th Cir 1906); State v. Burrows, 5 P. 449 (Kan. 1885); see also James, supra note 135, at 363-64 ("[T] he imprisonment is for the offense and not for the debt.").

178 See, e.g., ARK. CONST. art. II, $\S 16$ ("No person shall be imprisoned for debt in any civil action, on mesne or final process, unless in cases of fraud."); MICH. CONST. art. I, $\S 21$ ("No person shall be imprisoned for debt arising out of or founded on contract, express or implied, except in cases of fraud or breach of trust."); Bray v. State, 37 So. 250 (Ala. 1904); In re Sanborn, 52 F. 583, 584 (N.D. Cal. 1892).

179 See James, supra note 135, at 366. At that time, it appears the technical name for the legal action was a "bastardy proceeding." See id.

180 See id. at 367.

181 See, e.g., Bullen v. State, 518 So.2d 227, 233 (Ala. Cr. App. 1987)

182 See, e.g., Davis v. State, 185 So. 774, 776 (Ala. 1939); In re Wheeler 8 P. 276 (Kan. 1885).

${ }^{183}$ See, e.g., State v. Dowling, 110 So. 522 (Fla. 1926); Plapinger v. State,120 S.E.2d 610, 611 (Ga. 1961); Boyer v. Kinnick, 57 N.W. 691 (Iowa 1894); State v. Casady, 191 P.3d 1130 (Kan. 2008). It's interesting to note that the Illinois state constitution specifically includes criminal fines. See ILL. ConsT. art. I, § 14 ("No person shall be imprisoned for debt unless he refuses to deliver up his estate for the benefit of his creditors as provided by law or unless there is a strong presumption of fraud. No person shall be imprisoned for failure to pay a fine in a criminal case unless he has been afforded adequate time to make payment, in installments if necessary, and has willfully failed to make payment.").

184 See, e.g., Austin v. Seattle, 30 P.2d 646, 648 (Wash. 1934); Voelkel v. City of Cincinnati, 147 N.E. 754, 756-57 (1925); Turner v. Gruver, 168 So.2d 192, 193 (Fla. 1964); City of Fort Madison v. Bergthold, 93 N.W.2d 112 (Iowa 1958).

185 See, e.g., State v. Stone, 188 So. 575 (Fla. 1939); State v. Hopp, 190 N.W.2d 836 (Iowa 1971); State v. Krumroy, 923 P.2d 1044 (Kan. 1996).

186 See, e.g., Dozer v. Dozier, 850 P.2d 789 (Kan. 1993); State v. Stone, 188 So. 575 (Fla. 1939); Roach v. Oliver, 244 N.W. 899 (Iowa 1932).
} 
generally be discharged, such as taxes, damages for willful and malicious torts, domestic support, fines, penalties, and student loans. ${ }^{187}$

\section{The True Historical Antecedents}

This history, though, draws out a troublesome feature of the connection between the new debtors' prisons and the old: historically and doctrinally, they don't look the same at all. To the contrary, the new debtors' prisons exist exclusively within the doctrinal carve-out for crime, a carve-out the abolition movement seemed content to leave alone. And because the source of the debt is criminal, not contractual, the policy rationales that fueled the abolitionist movement don't seem to apply.

And there's an heir with better claim to the title. The law of remedies enables courts to issue civil contempt orders to induce compliance with court orders. While the practice of using this ability to enforce contractual debt seems to be rare, some authors in the legal literature have lambasted its use as creating a de facto debtors' prison regime in the United States. ${ }^{188}$ This practice is particularly concerning when the creditors at issue are payday lenders - who seem as likely merely to threaten imprisonment as they are actually to use it. ${ }^{189}$

187 See generally 11 U.S.C.A. § 523(1)-(14) (West 2012).

188 See Jayne S. Ressler, Civil Contempt Confinement and the Bankruptcy Abuse Prevention and Consumer Protection Act of 2005: An Examination of Debtor Incarceration in the Modern Age, 37 RUTGERs L.J. 355, 367 (2005) (discussing courts' use of contempt proceedings to enforce "a variety of fees and other expenses"); Lea Shepard, Creditors' Contempt, 2011 B.Y.U. L. REV. 1509, 1518 (detailing the commonlaw ability of creditors to bring in personam actions against debtors, enforced by the courts' contempt ability); $i d$. at 1526 (discussing "nonappearance contempt" for noshows). Richard E. James, by contrast, makes an argument that would have held wide appeal in the past, namely, that we should rigorously use imprisonment for nonpayment of civil debt to ensure that courts are respected and their judgments obeyed. See James, supra note 135, at 145 (2002). Authors have pointed out, too, that statutes enable imprisonment for failure to pay child support or alimony. See Ressler, supra, at 363. Still other authors have expressed concern with imprisonment for contractual debts owed to the state. See Vogt, supra note 38, at 335-36 (panning the use of imprisonment for failure to return military equipment after discharge).

189 See, e.g., Jim Gallagher, Illinois law limits "debtors prison" (July 26, 2012), http://www.stltoday.com/business/local/illinois-law-limits-debtors-

prison/article_422369fc-d76a-11e1-8d07-001a4bcf6878.html; Letter from Deborah Fowler, Deputy Dir., Texas Appleseed, and Ann Baddour, Dir., Fair Financial Services Program, to the Hon. Richard Cordray, Dir., Consumer Financial Protection Bureau et. al. (Dec. 17, 2014) (expressing "deep concern" about the use of "criminal charges by payday loan businesses to collect debts" in certain jurisdictions of Texas), available 
Furthermore, what's happening today has more natural legal ancestors in other institutions. One more plausible, legal-historical cosmogony is that the modern debtors' prisons are really the latest reincarnation of America's perennial struggle with racism and the legacy of slavery. Historians such as David Oshinsky, Douglas Blackman, and Mary Ellen Curtin have all documented the rise of the convict-leasing system in the American south in the years immediately following the Civil War, ${ }^{190}$ until it was abolished in Alabama in the late 1920s. ${ }^{191}$ That system had much in common with the new debtors' prisons. Once the Thirteenth Amendment made slavery unconstitutional, certain southern states immediately attempted to achieve the same functional result through a rash of new crimes, such as vagrancy (inability to prove employment), that were enforced only against blacks and rested handily within the Amendment's carve-out for crime. ${ }^{192}$ One simple legal innovation later, black convicts were being leased out to private corporations engaged in the massive undertaking of industrializing the South, ${ }^{193}$ laboring in railways, sawmills, cotton fields and coal mines under conditions so horrible their stench seeps through the historians' pages. ${ }^{194}$ By the end of the 1880 s, over 10,000 black convicts were engaged in forced labor in fields, work camps, and mines. ${ }^{195}$ Mississippi's 1876 Leasing Act captured anyone who couldn't pay the fines and court costs, ${ }^{196}$ an eerily familiar

http://www.texasappleseed.net/index.php?option=com_docman\&task=doc_download\& gid $=1181 \&$ Itemid $=$.

190 See generally DAVID M. Oshinsky, Worse than Slavery (1996); Douglas A. Blackmon, Slavery By Another Name (2008); Mary Ellen Curtin, Black PRISONERS AND THEIR WORLD (2000).

191 See OsHINSKY, supra note 190, at 56.

192 See, e.g., BLACKMON, supra note 190, at 53; OshINSKY, supra note 190, at 21; see also U.S. CONST. amend. XIII, § 1 ("Neither slavery nor involuntary servitude, except as a punishment for crime whereof the party shall have been duly convicted, shall exist within the United States, or any place subject to their jurisdiction.") (emphasis added).

193 See, e.g., BlaCKMON, supra note 190, at 54-55 (discussing "leasing prisoners to private parties"); 65-66 (noting that arrests rose and fell with the need for labor).

${ }^{194}$ For an extended account, see BLACKMON, supra note 190, at 311-320 (detailing the utterly unconscionable conditions of life and death in the prison slave mines in 1908); see also OsHINSKY, supra note 190, at 36; id. at 59 ("On many railroads, convicts were moved from job to job in a rolling iron cage, which also provided the lodging . . . . [for] upwards of twenty men. . . . The prisoners slept side by side, shackled together, on narrow wooden slabs. They relieved themselves in a single bucket and bathed in the same filthy tub of water. With no screens on the cages, insects swarmed everywhere. It was like a small piece of hell, an observer noted the stench, the chains, the sickness, and the heat.").

195 BLACKMON, supra note 190, at 90.

196 OSHINSKY, supra note 190, at 41-42. 
tactic. On this account, the use of crime (or alleged crime ${ }^{197}$ ) to control populations of color is hardly new, the second-best strategy of white supremacy after property. ${ }^{198}$ The Fourteenth and Fifteenth Amendments blocked more obvious instances of this racist spirit, but the workarounds persisted from Reconstruction into the Civil Rights Era. For historian Michelle Alexander, the age of mass incarceration is just the latest manifestation of American die-hard racist attitudes: the "new Jim Crow."199

Another legal-historical account would put less emphasis on race and more on class. The new debtors' prisons, on this view, are just the latest manifestation of the underbelly of capitalism: an exploited working class. Political scientist Marie Gottschalk, for example, wants to ensure we don't lose track of the importance of the rise of neoliberalism in our account of mass incarceration. ${ }^{200}$ Historian Heather Ann Thompson points out that American employers have found prison labor to be extremely attractive, due to low wages, benefits, and liabilities. 201 Private companies that have leased convict labor include Starbucks, Microsoft, Wal-Mart, Victoria's Secret, Honda, and Merrill Lynch. 202 Similarly, a number of commentators have pointed out that the availability of prison labor saps unions of

197 Blackmon, among others, notes that the system made it easy for white southerners to accuse black men of debt and fraud, process them rapidly through a corrupt criminal justice system, and then profit by their labor. See BLACKMON, supra note 190, at 7 ("Instead of thousands of true thieves and thugs drawn into the system over decades, the records demonstrate the capture and imprisonment of thousands of random indigent citizens, almost always under the thinnest chimera of probable cause or judicial process."); see also id. at 132, 148.

198 See, e.g., BLACKMON, supra note 190, at 287 ("Alabama's slave system had evolved into a forced labor agricultural and industrial enterprise unparalleled in the long history of slaves in the United States.").

199 See Michelle Alexander, The New Jim Crow (2013); see also Blackmon, supra note 190, at 384 ("AAmericans] recoil from the implication that emancipated black Americans could not exercise freedom, and remained under the cruel thumb of white America, despite the explicit guarantees of the Constitution, the Fourteenth and Fifteenth amendments, and the moral resolve of the Civil War."). But see MARIE GotTschalk, CAUGht 119-20 (2015) (critiquing a narrow race lens for failing to produce a workable solution, account for the effects of neoliberalism, capture prison conditions, and engage with new demographic changes).

200 See GoTTSCHALK, supra note 199, at 139. Gottschalk specifically points out that the increase in racial disparity took place before the burgeoning of the American prison system and that, absent racial disparities, we'd still have a prison crisis by most measures, see id. at 121.

${ }^{201}$ Heather Ann Thompson, Why Mass Incarceration Matters: Rethinking Crisis, Decline, and Transformation in Postwar American History, 97 J. AM. Hist. 703, 722 (2010).

202 See id. at 720 n.39. 
bargaining power. ${ }^{203}$ Sociologist Loïc Wacquant has referred to this phenomenon as "the criminalization of poverty that is the indispensable complement to the imposition of precarious and underpaid wage labor as civic obligation for those trapped at the bottom of the class and caste structure."204

The ultimate sufficiency of these alternate lenses is beyond our scope here. But their prima facie applicability might well leave us wondering how the old and new debtors prisons are related — if at all.

\section{The Functional Connection}

And yet - it can't be said that the old institution of the old debtors' prisons, and its abolition, has nothing to say to the new. To the contrary, despite the historical and doctrinal gap, there's a deeper connection, a functional one. This Part argues that, in at least three areas, the lessons American society learned in the nineteenth century can still apply today.

\section{A. Incarceration and Its Inefficiencies}

First, imprisonment as a punitive technique is a blunt instrument, no matter what doctrinal breach leads to its imposition. For some purposes, of course, blunt instruments may come in handy. But the abolitionists emphasized that imprisoning individuals who otherwise could work carried heavy social costs in addition to the costs of debtor upkeep. The risk of malnutrition, disease, and death that skyrocketed in close quarters seemed less and less worth it. Prison was socially disruptive, too: even though debtors were separated from the general population, they were nonetheless treated as criminals and, as the abolitionists complained, like slaves.

Today, American society faces exactly the same concerns in the new debtors' prisons. The carceral state incurs extremely high fixed and

\footnotetext{
${ }^{203}$ See, e.g., Thompson, supra note 201, at 717 (noting that prison labor contributed to the decline of the strengths of unions in the second half of the twentieth century); BLACKMON, supra note 190, at 90 (noting the convict-labor system served also as a defense against unions).

${ }^{204}$ Loïc Wacquant, The Place of the Prison in the New Government of Poverty, in AfTER the WAR ON CRIMe 23, 25 (Mary Louise Frampton et al. eds., 2008). For Wacquant and many other theorists, the problem is tied up in welfare policy as well. See id.
} 
variable costs, ${ }^{205}$ and those who have been imprisoned find it very difficult to obtain work after their release. This is due not only to social stigma, ${ }^{206}$ but also to collateral consequences such as the loss of a driver's license or ineligibility for certain jobs. ${ }^{207}$ Unlike the debtors' prisons of old, we do not separate out our debtors, putting those guilty of inability to pay alongside those convicted of more serious crimes. ${ }^{208}$ Furthermore, as in the context of commercial debtors' prisons, "ability to pay" is not endogenous to the sanctions wielded against the debtor: here, as there, the threat of imprisonment increases the risk that the debtor will turn to those not legally obligated to pay — or to illegal sources of money. 209

In the past, the erstwhile efficiency of debtors' prisons was undermined by rapidly improving alternatives - secured credit, equity financing, and credit reporting in the commercial sphere. ${ }^{210}$ These cost-effective methods of credit financing enabled the scientific, rational regulation of credit ex ante, spreading out the costs of bad debt through interest rates. Such methods were far superior to the threat of imprisonment ex post. Today, opportunities for flexible payment schedules, ${ }^{211}$ community service, ${ }^{212}$ and informal sanctions ${ }^{213}$

205 See, e.g., Christian HenRichson \& Ruth Delaney, VERA Inst. OF Justice, The PRICE OF PRISONS: What InCARCERATION COSTS TAXPAYERS 2 (July 20, 2012), http://www.vera.org/sites/default/files/resources/downloads/price-of-prisons-updatedversion-021914.pdf.

206 See, e.g., Complaint, Fant v. Ferguson, at 19 ("Because of [Mr. Nelson's] recent jailings - including one while he was in uniform on his way to an important painting job - he has lost a number of jobs and finds it difficult to be re-hired because painting contractors know that he could be jailed on the way ....").

207 See, e.g., Natapoff, supra note 3639, at 1089-91. Other scholars have pointed out that, in some states, these debtors are disenfranchised until they pay back their entire debt to the state. See Ann Cammett, Shadow Citizens: Felony Disenfranchisement and the Criminalization of Debt, 177 PenN. ST. L. Rev. 349 (2012).

208 Accord Westen, supra note 37, at 793.

${ }^{209}$ Bearden v. Georgia, 461 U.S. 660, 670-71 ("Revoking the probation of someone who through no fault of his own is unable to make restitution will not make restitution suddenly forthcoming. Indeed, such a policy may have the perverse effect of inducing the probationer to use illegal means to acquire funds to pay in order to avoid revocation.").

210 See supra notes 161-163 and accompanying text.

211 See Bearden, 461 U.S. at 672 ("[G]iven the general flexibility of tailoring fines to the resources of a defendant, or even permitting the defendant to do specified work to satisfy the fine ... a sentencing court can often establish a reduced fine or alternate public service in lieu of a fine that adequately serves the State's goals of punishment and deterrence .....") (citations omitted).

212 See law

${ }^{213}$ For a discussion of the academic debate on informal sanctions, see Dan M. Kahan, What's Really Wrong with Shaming Sanctions, 84 TEX. L. REV. 2075, 2078-79 (2006). 
make it similarly hard to believe that incarceration for debt is the cheapest tool for most penal purposes. This is especially true in most of the imprisonment-for-debt cases, where the underlying offense generally does not indicate that the offender must be incapacitated or severely punished for the benefit of society.

Of course, if the ultimate objective of the state in wielding imprisonment is to fund the government, imprisoning those who could otherwise be released to seek employment seems similarly irrational. ${ }^{214}$ Just as the ban on debtors' prisons forced creditors and debtors to seek alternatives through better information or quasiinsurance in the form of higher interest rates, cutting back on imprisonment for criminal costs would not leave state and municipal governments powerless to act, it would simply remove the most onerous and inefficient form of collection action - and require them to find more cost-effective ways of funding the criminal justice system.

\section{B. Civil Debts in Criminal Law}

Second, even though the debts of the modern debtors' prison arise ex delicto, not ex contractu (the terminology some courts use), many of these monetary obligations actually seem quite civil in various respects.

Setting aside (for now) the fine itself, court costs and fees are more obviously grounded in the goal of funding the government. Insofar as they pay for fixed costs, they seem akin to a general tax; insofar as they pay for variable costs, they are properly analogized to a fee for service. Even interest meets this definition, as it covers the time-value of the money the state spent on the debtor's process. The widespread and harshly criticized phenomenon of privatization in the criminal justice system ${ }^{215}$ makes a number of these debts seem even more civil: they're owed to private, for-profit institutions which, by virtue of their contractual relationship to the state, can threaten arrest and imprisonment for nonpayment. ${ }^{216}$ If court costs, fees, and interest reflect the offender-funded model of the criminal justice system, it's properly described as a regressive tax, imposing the costs of the system upon those least able to pay. ${ }^{217}$

\footnotetext{
${ }^{214}$ Of course, as one reader pointed out, the problem in Ferguson isn't so much irrational means as rational ones, serving evil ends.

215 See generally Note, Policing and Profit, 128 HARV. L. REV. 1723 (2015).

216 See, e.g., id. at 1723, 1726.

217 See id. at 1728, 1734; Natapoff, supra note 36, at 1098 and n.208.
} 
And while fines are probably grounded in the core of a state's "penological interests" 218 "in punishment and deterrence," 219 that framing of fines is open to question, too. Westen points out (cautiously) that the fine was originally developed in England when the state needed money and jail was cheap. ${ }^{220}$ And if fines are actually about deterrence, it's not clear why the American system is the regressive counterpart of the Scandinavian day-fine system, which imposes a graduated system of fines based on the individual's daily salary. ${ }^{221}$ The civil nature of the fine is especially open to question for strict liability offenses, where the behavior was not criminal at common law and the authorizing statute does not provide for imprisonment. The argument that imprisonment for nonpayment of fines triggers a civil dimension of the law strikes a blow at what many may consider to be at the core of criminal law, ${ }^{222}$ but that's perhaps an endeavor worth commencing. ${ }^{223}$ After all, "law reaches past formalism." 224

Of course, one might counter that the baseline costs of government that should be funded through tax do not include the variable costs of infractions or crimes. Thus, when an offender triggers the criminal justice system, it is both fair and efficient to ask her to pay. Fair, because that individual is the proximate cause of the variable cost, and efficient, because that individual faces the deterrent effect of the full costs of her choice. But it's highly implausible that the dollar amounts of these fines and fees are empirically tethered down to the actual marginal costs of the justice system, and in any case this counter misunderstands the destination of the argument: the issue here isn't

\footnotetext{
218 Bearden v. Georgia, 461 U.S. 660, 670 (1982).

219 Id. at 672 .

${ }^{220}$ Westen, supra note 37, argues that the historical pedigree of imprisonment for nonpayment of fines should "give us pause," $i d$. at 779, before we come to the conclusion that nonpayment of fines is illegitimate. Yet, he says, in today's world, "a careful reexamination of the penology and legality of fines is badly needed," $i d$. at 786-87.

221 Some members of the law-and-economics school would support the Scandinavian model, at least under certain conditions. See A. Mitchell Polinsky \& Steven Shavell, The Optimal Use of Fines and Imprisonment, 24 J. PUB. ECON. 89 (1984).

222 Such a move is perhaps the reverse of Cardozo's famous phrase, "assault upon the citadel of privity," speaking of strict liability to consumers on the part of manufacturers. See William L. Prosser, The Assault Upon the Citadel (Strict Liability to the Consumer), 69 YALE L.J. 1099, 1099 (1960) (quoting Ultramares Corp. v. Touche, 174 N.E. 441, 445 (1931)).

${ }^{223}$ Cf. Complaint, Fant v. Ferguson, at 33 ("Decisions regarding the operation of the court and the jail - including but not limited to the assessment of fines, fees, costs, and surcharges ... are significantly influenced by and based on maximizing revenues collected rather than on legitimate penological considerations.").

${ }^{224}$ Lee v. Weisman, 505 U.S. 577, 595 (1992).
} 
about the propriety of assessing these costs — which is itself questionable 225 - it's about what sanctions can be used to enforce collection.

\section{Crime, Contract and Situationism}

Third, just as it came to be seen as inefficient and unfair to punish people harshly for breach of contract in a fast-paced commercial world, so too society may come to see certain kinds of criminal behavior as products of the external world, and less under the control of the offender. ${ }^{226}$ American society, given its history, has particular reason to question any crimes that seem to punish people more for their race or for their poverty than for their behavior. And there's reason to think that these sorts of "crime-traps" are happening, at least to some extent. ${ }^{227}$ If that's right, then, just as the abolition of debtors' prison in the commercial context forced lenders to bear the risk of improvident lending, so too, in the criminal context, abolition would force society to take responsibility for ensuring that fewer infractions occur - a task that might be accomplished through better support, education, and policing. ${ }^{228}$

At the same time, even a widespread lessening in the social stigma attached to a particular behavior might not be enough to defeat the deterrence justification for imprisonment. In a debt contract, both the lender and the debtor have the ability to walk away. But one could argue that such shared control is not the case for the types of offenses we're concerned with today. Still, this rationale seems only persuasive for crimes serious enough to merit a sentence of imprisonment as punishment.

Moreover, the decriminalization of certain forms of behavior would likely only evolve incrementally, and might preferably be deployed by democratically accountable legislatures than by courts. Still,

\footnotetext{
225 See, e.g., Natapoff, supra note 36, at 1100.

${ }^{226}$ Cf. Jon Hanson \& Kathleen Hanson, The Blame Frame: Justifying (Racial) Injustice in America, 41 HARV. C.R.-C.L. L. REV. 413, 418-25 (2006) (describing the inverse process, by which we blame victims for the injustices they suffer); see also Richard Delgado, "Rotten Social Background": Should the Criminal Law Recognize a Defense of Severe Environmental Deprivation?, 3 LAW \& INEQ. 9, 10, 23-33 (1985) (arguing some criminal activity may come from poverty).

227 See supra notes 60-63 and accompanying text.

228 See, e.g., Barack Obama, President of the United States, Remarks by the President at the NAACP Conference (July 14, 2015), available at https://www.whitehouse.gov/the-press-office/2015/07/14/remarks-president-naacpconference.
} 
American society experienced a rapid sea change in our attitudes toward debt across the long nineteenth century - and given the longstanding critique of American criminal law, we might well see the same with crime.

\section{REINVIGORATING THE BAN}

Based on these three areas of similarity, the ban on the old debtors' prisons could plausibly be extended to cover some aspects of the new. This Part turns to explore the relevant legal texts - the doctrinal how - and suggests where a New Abolitionist movement might be needed to produce and deploy new legal texts.

Of course, the state constitutional and statutory laws described above already regulate imprisonment for debt, and they might apply to some aspects of the new debtors' prisons, either on their own terms or because federal equal protection requires states to treat certain types of debts similarly. In addition to those imprisonment-for-debt clauses, federal equal protection jurisprudence regulates the extent to which states can treat indigent and nonindigent debtors differently. ${ }^{229}$ Three cases from the 1970s and 1980s, Williams $v$. Illinois, ${ }^{230}$ Tate $v$. Short, ${ }^{231}$ and Bearden v. Georgia, ${ }^{232}$ all constrained the ability of courts to imprison criminal defendants for inability to pay fines, fees, and court costs.

As one might expect, there's some overlap, and enforcing Bearden protections should be a priority of the federal courts. But as it turns out, while the Bearden line of cases has been broadly applied across the spectrum of criminal debts, the protections it offers are limited. In some cases, the state debtors' prison bans - while not as broadly applicable - may provide defendants with more rigorous protections.

\section{A. The Indigent/Nonindigent Line: Bearden Claims}

The Bearden line of cases (including Williams and Tate) requires states not to discriminate based on ability to pay. The relevant equal protection classification is therefore indigent/nonindigent. Williams $v$. Illinois and Tate $v$. Short both addressed imprisonment for failure to

\footnotetext{
229 The equal protection clauses present in many state constitutions might do similar work, but have not been analyzed at length here.

230399 U.S. 235 (1970).

231401 U.S. 395 (1971).

232461 U.S. 660 (1982).
} 
pay debts imposed at sentencing. In Williams, the defendant was sentenced to one year imprisonment (the statutory maximum), a $\$ 500$ fine, and $\$ 5$ in costs. ${ }^{233}$ The sentence provided that if Williams was in default at the end of his prison term, he would be imprisoned further until he "work[ed] off" the debt at the rate of $\$ 5$ a day. ${ }^{234}$ The result was that Williams spent 101 days in prison beyond the statutory maximum. ${ }^{235}$ The Court vacated the judgment, holding that "when the aggregate imprisonment exceeds the maximum period fixed by the statute and results directly from an involuntary nonpayment of a fine or court costs we are confronted with an impermissible discrimination that rests on ability to pay." 236 The Court reasoned that it would violate the Equal Protection Clause 237 to allow a statutory maximum prison term statute to apply only to those who couldn't pay, and not to those who could. 238

Tate pressed forward the logic of Williams. In Tate, also decided within an equal protection framework, the governing statute provided only for fines for the relevant offense. ${ }^{239}$ On those facts, Tate might be viewed as just a particular example of the Williams holding, one where the statutory maximum was zero days. ${ }^{240}$ Indeed, that's how the Bearden Court read it. ${ }^{241}$ Still, the Court "adopt[ed]" the "view" that courts may not "jail] an indigent for failing to make immediate payment of any fine, whether or not the fine is accompanied by a jail term and whether or not the jail term ... extends beyond the maximum." 242

Bearden v. Georgia, decided about a decade later, took the issue into the procedural context of the revocation of parole. ${ }^{243}$ In Bearden, the defendant was ordered to pay a $\$ 500$ fine and $\$ 250$ in restitution

\footnotetext{
233 Williams, 399 U.S. at 236.

234 Id.

235 Id. at 237.

${ }^{236} I d$. at 240-41. The Williams Court treated its determination with regard to fines as determinative of its position on fees. It's not clear whether the Court saw fines and costs as completely equivalent - indeed, it acknowledges that they "reflect quite different considerations" while imprisonment in both contexts "ensur[es] compliance with a judgment" - but the issue was not, at least, squarely before the Court. Id. at 245 n.20.

237 U.S. CONST. amend. XIV.

238 See id. at 242.

239 Tate v. Short, 401 U.S. 395, 397 (1971).

240 See id. at 397-98.

${ }^{241}$ See Bearden v. Georgia, 461 U.S. 660, 664 (1982).

${ }^{242}$ Id. at 399 (citing Morris v. Schoonfield, 399 U.S. 508, 509 (1970)).

243 See Bearden, 461 U.S. at 661.
} 
over the course of four months as a condition of parole.244 After he was laid off, he had difficulty making his payments and was sentenced to prison for the remainder of his probationary period. ${ }^{245}$ Even though the resulting prison time would not have surmounted the statutory maximum, the Court held that the court couldn't automatically convert nonpayment into imprisonment: "if the State determines a fine or restitution to be the appropriate and adequate penalty for the crime, it may not thereafter imprison a person solely because he lacked the resources to pay it." 246 Writing for the Court in Bearden, Justice O'Connor said that both equal protection and due process analyses were triggered. ${ }^{247}$

All three cases recognized two limits on the protections they demanded, although only the first is particularly relevant for our purposes: ${ }^{248}$ in all three cases, the Court stressed that willful nonpayment was not protected. ${ }^{249}$ As the Bearden Court put it, the probationer needed to make "sufficient bona fide efforts to seek employment or borrow money . . .,"250 a standard which we'll call the "bona-fide-efforts test." Thus, willfulness doctrine under Bearden results in a heightened ability-to-pay threshold that demands not just the transfer of current assets, but also good faith efforts to secure new ones - including, the Supreme Court suggested, credit applications and job hunts. How courts apply Bearden's bona-fide-efforts test was left unspecified and unregulated, and the Court has never revisited the

\footnotetext{
$244 I d$. at 662.

$245 I d$.

246 Id. at 668.

247 See id. at $665-667$.

248 The Court also provided states with a carve-out when its traditional punitive goals could not be met by any other technique. See Tate, 401 U.S. at 400-01 ("Nor is our decision to be understood as precluding imprisonment as an enforcement method when alternative means are unsuccessful despite the defendant's reasonable efforts to satisfy the fines by those means; the determination of the constitutionality of imprisonment in that circumstance must await the presentation of a concrete case."). But it implied alternatives would be available in most cases. See Bearden, 461 U.S. at 672 ("Only if the sentencing court determines that alternatives to imprisonment are not adequate in a particular situation to meet the State's interest in punishment and deterrence may the State imprison a probationer who has made sufficient bona fide efforts to pay."). Lower courts have relied on that carve-out when defendants have committed other forms of unlawful behavior that call the probation into question, such as failing to file tax returns.

${ }^{249}$ In Williams, the Court emphasized that "nothing in our decision today precludes imprisonment for willful refusal to pay a fine or court costs." Williams, 399 U.S. at 242 n.19. Similarly, the Tate Court said, "We emphasize that our holding today does not suggest any constitutional infirmity in imprisonment of a defendant with the means to pay a fine who refuses or neglects to do so." Tate, 401 U.S. at 400.

250 Bearden, 461 U.S. at 668.
} 
issue. But in reviewing the determinations of lower courts - factual determinations subject to review for clear error ${ }^{251}$ - state and federal appellate courts have affirmed that some effort to find employment is required, ${ }^{252}$ and some have put the burden on the debtor or have established a burden-shifting framework. ${ }^{253}$

At the same time, just as Bearden extended the rule of Williams and Tate to the context of revocation of parole, equal protection of indigent debtors seems to have been applied across the full spread of criminal debts (although it doesn't confine a judge's discretion to consider financial background at sentencing 254 ). Courts have held that supervised release is sufficiently similar to parole for the Bearden rule to apply. ${ }^{255}$ But courts disagree over whether Bearden applies as well

251 See, e.g., U.S. v. Montgomery, 532 F.3d 811, 814 (8th Cir. 2008); U.S. v. Nevis, 108 F.3d 340, 340 (9th Cir. 1996).

${ }^{252}$ Compare Martin v. Solem, 801 F.2d 324, 332 (8th Cir. 1986) (finding that the debtor was "not totally disabled and had some ability to work . . odd jobs . . . cannot meet the Bearden test"), with U.S. v. Davis, 140 F. App'x 190 (11th Cir. 2005) (failure to seek employment as an appropriate factor).

${ }^{253}$ See, e.g., State v. Bower, 823 P.2d 1171, 1174-75 (Wash. Ct. App. 1992) (holding that a debtor "should be prepared to show the court his actual income, his reasonable living expenses, his efforts, if any, to find steady employment, [and] his efforts, if any, to acquire resources from which to pay his court-ordered obligations . . . .); U.S. v. Brown, 899 F.2d 189, 194 (2d Cir. 1990) ("[T]he probationer is entitled to an opportunity to demonstrate that there was a justifiable excuse for any violation that occurred . . . .); U.S. v. Pinjuv, 218 F.2d 1125, 1133 (9th Cir. 2000) ("No evidence was submitted in this matter by Pinjuv that her disruptive conduct was involuntary."); Del Valle v. State, 80 So.3d 999, 1015 (Fla. 2011) (establishing burden-shifting framework); see also Del Valle, 80 So.3d at 1014 n.10 (listing cases). But see U.S. v. Johnson, 347 F.3d 412, 416 (2nd Cir. 2003) ("[T]he [Bearden] Court held that a defendant's probation could not be revoked for failure to pay a fine or restitution without evidence and findings that he was responsible for the default ....").

254 See Williams v. Illinois, 399 U.S. 235, 243 (1970) ("The mere fact that an indigent in a particular case may be imprisoned for a longer time than a non-indigent convicted of the same offense does not, of course, give rise to a violation of the Equal Protection Clause. Sentencing judges are vested with wide discretion in the exceedingly difficult task of determining the appropriate punishment in the countless variety of situations that appear."). In Bearden, Justice O'Connor opined in dicta that equal protection had no purchase at the sentencing stage, where financial background was a "point on a spectrum rather than a classification." Bearden $v$. Georgia, 461 U.S. 660, 666 n.8 (1983). She suggested that due process could strike down such sentencing considerations that were "so arbitrary or unfair as to be a denial of due process," $i d$., but went on to give sentencing judges the green light to consider financial background, see id. at 669-70 (courts can consider the "entire background of the defendant, including his employment history and financial resources"). A case on this issue is currently up for review by the Florida Supreme Court, although not with oral argument. See Noel v. State, 2014 WL 7004962 (Fla. Dec. 5, 2014) (slip op.).

255 See, e.g., U.S. v. Montgomery, 532 F.3d 811, 813 (8th Cir. 2008). 
to debts incurred as part of a plea bargain. 256 That's quite important, as plea-bargaining comprises the vast majority of the resolution of criminal cases. ${ }^{257}$

Characterizing federal protections under Bearden, then, we might say that they have a broad scope of application - the full range of criminal monetary sanctions and charges, at every procedural stage but a high threshold before its protections kick in - the bona-fideefforts test. How courts should apply that threshold has been left as a vague factual determination that leaves discretion with the same judges who preside over the troublesome hearings in Ferguson and elsewhere. ${ }^{258}$ Bearden's protections could be enhanced by a statutory rule or presumption that SNAP-eligibility, or some other proxy for indigence, means the debtor has met the bona-fide efforts test. ${ }^{259}$ At the very least, statutes (like Colorado's) that require courts to conduct their Bearden hearings on the record will enable the appellate system to look more intelligently at the most appropriate considerations. ${ }^{260}$

Thus, Bearden claims ${ }^{261}$ can go a long way in challenging the new debtors' prisons. Ignorance and flagrant disregard of Bearden may be

256 Compare Commonwealth v. Marshall, 345 S.W.3d 822, 829-30 (Ky. 2011), with State v. Nordahl, 680 N.W.2d 247 (N.D. 2004). Holding that Bearden didn't apply to plea bargaining, the North Dakota Supreme Court suggested in State v. Nordahl that the breach of a plea bargaining agreement suggested either that the defendant misrepresented his assets ex ante or didn't adequately secure them to pay the debt ex post. The court was particularly concerned about allowing debtors to bargain their way out of criminal sanctions in bad faith. See id. at 253. Alternatively, then, we might say either that Bearden doesn't apply to defendants who breach their plea bargaining obligations - or that breach of such obligations is a per se failure of Bearden's bona-fide-efforts test. See, e.g., id. at 252 ("Nordahl is presumed to have had knowledge of his assets and obligations at the time he entered into the plea agreement. Nordahl entered into security agreements in order to secure financing. Nordahl knew or should have known the encumbrances on his assets could frustrate his ability to liquidate and fulfill the restitution obligation."); $i d$. (“[P]rior knowledge of inability to pay negates the good faith efforts present in the Bearden ruling."); accord Dickey v. State, 570 S.E.2d 634, 636 (Ga. Ct. App. 2002); Patton v. State, 458 N.E.2d 657, 658-60 (Ind. Ct. App. 1984).

257 See, e.g., Lindsey Devers, Bureau of Justice Assistance, Plea and Charge BARGAINING: RESEARCH SUMMARY (2011) (estimating that between 90 and 95\% of state and federal criminal cases end in a plea bargain).

258 See Recent Legislation, supra note 69, at 1316.

259 See id. at 1319.

260 See id. at $1315-16$.

261 And, perhaps, their state counterparts. See supra note 229. 
the biggest problem. ${ }^{262}$ Still, there's reason to look to state constitutional and statutory law for additional firepower. ${ }^{263}$

\section{B. The Civil/Criminal Line: Imprisonment-for-Debt Claims}

\section{Expanding the Scope of the Ban}

As noted above, the state constitutional bans on imprisonment for debt uniformly exempt crime from their scope. Some monetary obligations generated by crime, like fines, don't seem easily swept under the imprisonment-for-debt provisions. ${ }^{264}$ But there are two kinds of criminal monetary sanction that states might nonetheless hold to be subject to the ban.

\section{a. Strict Liability Offenses}

First, so-called "public welfare" or "strict liability" offenses, particularly where the statute only authorizes monetary fines. Although at common law scienter requirements (mens rea) were generally necessary to a criminal charge, ${ }^{265}$ the development of criminal law for regulatory purposes has made it increasingly necessary to dispense with scienter in a number of cases. As the Court said in Morissette v. United States:266

[Public welfare offenses] do not fit neatly into any of such accepted classifications of common-law offenses, such as those against the state, the person, property, or public morals. Many of these offenses are not in the nature of positive aggressions or invasions, with which the common law so often dealt, but are in the nature of neglect where the law requires care, or inaction where it imposes a duty. Many violations of such regulations result in no direct or immediate injury to person or property but merely create the danger of probability of it which the law seeks to minimize. ${ }^{267}$

262 See Natapoff, supra note 36, at 1085.

${ }^{263}$ Natapoff also discusses ways courts attempt to get around the constitutional prohibitions through civil contempt, see id. at 1085-86. This may be better characterized as an example of ignoring Bearden than skirting around it - how can one constitutionally be found in civil contempt of an order the court had no constitutional authority to issue? - but a good case on point, to my knowledge, has yet to be decided.

264 See supra note 220.

265 See United States v. Balint, 258 U.S. 250 (1992) ("While the general rule at common law was that the scienter was a necessary element in the indictment and proof of every crime ... there has been a modification of this view in respect to prosecutions under statutes the purpose of which would be obstructed by such a requirement."); Jerome Hall, Interrelations of Criminal Law and Torts: I, 43 CoLUM. L. REV. 753767 (1943) ("Actus non facit reum, nisi mens sit rea is the most general doctrine on culpability in the criminal law.").

266342 U.S. 246 (1952).

267 Id. at $255-56$. 
When trying to determine whether or not to read a scienter requirement into a statute, courts are guided by principles like those laid out in Morissette, looking to the presence or absence of a culpable mental state, the purpose of the statute, its connection to common law, whether or not it is regulatory in nature, whether it would be difficult to enforce with a scienter requirement, and whether the sanction is not severe. ${ }^{268}$

At the outset - to help motivate the argument - recall the critiques of the modern debtors' prison discussed above. Remember Ferguson. While some of the underlying charges, like prostitution or domestic disputes, might entail a mens rea, much of the fervor has centered on regulatory crimes, such as traffic fines. Sweeping certain strict liability offenses under the debtors' prison ban would capture the bulk of the legal actions and deal a major blow to the modern debtors' prisons. And it would do so by drawing a sharp line between two distinguishable domains of criminal law. 269

And there are good rationales for including such offenses where constitutionally possible. To be fair, the provisions limiting the ban to debts arising ex contractu ${ }^{270}$ seem inhospitable to this interpretation. But in states whose constitutional provisions restrict the ban to "civil actions," 271 that exempt out "fines and penalties imposed for the violation of law," 272 or whose caselaw has specifically mentioned "crime," 273 an originalist meaning of those provisions might nonetheless exclude strict liability crimes, as such crimes only became prominent within American criminal law after the abolition of debtors' prisons. ${ }^{274}$ The Morissette Court identified the "pilot of the movement"

\footnotetext{
268 See, e.g., State v. Phillips, 771 So.2d 1061 (Ala. Crim. App. 1998).

${ }^{269}$ Cf. William J. Stuntz, The Pathological Politics of Criminal Law, 100 Mich. L. REV. 505, 512 (2001) ("[C]riminal law is not one field but two. The first consists of a few core crimes ... murder, manslaughter, rape, robbery, arson, assault, kidnapping, burglary, larceny, and auto theft. The second consists of everything else.”).

270 E.g., Mich. ConsT. art. I, § 21 ("No person shall be imprisoned for debt arising out of or founded on contract, express or implied ...."); S.C. ConsT. art. VI, § 24 ("No person shall be imprisoned for debt arising out of or founded upon a contract"); S.D. CONST. art. IV, $§ 15$ (same).

${ }^{271}$ E.g., ARK. CONST. art. II, § 16.

272 OKLA. CONST. art II, § 13.

${ }^{273}$ E.g., Plapinger v. State, 120 S.E.2d 609, 611 (Ga. 1961) ("The rule is that the constitutional provision prohibiting imprisonment for debt is not violated where the legislative purpose is to punish for an act declared criminal, not to enforce imprisonment for debt.")

274 See generally Francis Bowes Sayre, Public Welfare Offenses, 33 CoLum. L. REv. 55 (1933). Jerome Hall, writing in 1941, said, "[The act requirement] and the mens rea principle constituted the two most basic doctrines of [Blackstone's] treatise on criminal law. They are still generally accepted as such in this country.” Jerome Hall,
} 
as such crimes as "selling liquor to a habitual drunkard" and "selling adulterated milk," citing cases from 1849,275 1864,276 and 1865.277 A law review article, published in 1933, called the "steadily growing stream of offenses punishable without any criminal intent whatsoever" a "recent movement" in criminal law. ${ }^{278}$ That same article, like the Court in Morissette, placed the beginnings of the trend in the middle of the nineteenth century. ${ }^{279}$ So placing strict liability crimes under the ban may have a solid originalist pedigree - in addition to making functional sense.

The clearest cases are strict liability crimes where the statute authorizes only nominal or modest fines, such as many traffic offenses. As the Ohio Supreme Court put it, "In today's society, no one, in good conscience, can contend that a nine-dollar fine for crashing a stop sign is deserving of three days in jail if one is unable to pay."280 Many state courts - depending on the text of their constitutions - could hold that such fines constitute civil "debt" under their state constitutional bans. On that holding, if the legislature felt that imprisonment were a necessary sanction to place in the trial court's toolbox, it would have to amend the statute to provide for it.

Even if a court were reluctant to issue a constitutional holding, a similar result would be achieved if it deployed the constitutional avoidance canon: since enabling imprisonment for debt rising from a strict liability offense would raise a serious constitutional issue, the court could interpret such statutes as falling under the ban absent a clear statement from the legislature specifically providing for imprisonment upon default.

Prolegomena to a Science of Criminal Law, 89 U. PENN. L. REV. 549, 557-58 (1941). Yet Hall was critiquing a blind adherence to mens rea as a ubiquitous doctrine in criminal law. See id. at 558 (arguing that mens rea, like the act requirement, becomes "little more than a point of orientation . . . . once we encounter involuntary manslaughter, other crimes of negligence, and various statutory offenses.").

275 Morissette v. U.S., 342 U.S. 246, 256 (1952) (citing Barnes v. State, 19 Conn. 398 (Conn. 1849)).

${ }^{276}$ Id. (citing Commonwealth v. Farren, 91 Mass. 489 (Mass. 1864)).

277 Id. (citing Commonwealth v. Nichols, 92 Mass. 199 (Mass. 1865) and Commonwealth v. Waite, 93 Mass. 264 (Mass. 1865))

278 Sayre, supra note 274 , at 55.

279 See id. at 56. Cf. Myers v. State, 1 Conn. 502 (1816) (holding that a defendant who rented his carriage on Sunday, a crime punishable by a fine of twenty dollars, couldn't be found guilty without a showing of mens rea); see also Stuntz, supra note 269, at 513-14 (describing the massive growth in statutory offenses in several states from the second half of the nineteenth century until today). Stuntz had also noted that "[the] two fields have dramatically different histories." Id. at 512.

280 Strattman v. Studt, 253 N.E.2d 749, 753 (Ohio 1969). 


\section{b. Costs}

Second, costs. Despite arising out of a criminal proceeding, costs on some accounts are cleanly distinguishable from fines, restitution, and forfeiture in their basic purpose: compensating for or subsidizing the government's marginal expenditures on criminal proceedings. But of course, funding the government is not one of the traditional purposes of penal law.

Unlike strict liability offenses, the historical pedigree of imposing costs on defendants long antedates the abolition of debtors' prison. But its quality as criminal has been contested. Before laying out the argument, it's worth noting that the majority rule holds that costs fall outside the scope of the ban. Here's an extreme case, from 1905. In $E x$ parte Diggs, ${ }^{281}$ the defendant, Diggs, was sentenced to jail for ninety days for assault, a fine of $\$ 50$, costs of $\$ 16.40$, and jail fees of $\$ 2 .{ }^{282}$ Diggs was sent into the employ of a private contractor, Williams, to work off the remainder of his debt. ${ }^{283}$ Williams then furnished Diggs with $\$ 15$ worth of clothing and shoes, ${ }^{284}$ as required by statute. ${ }^{285}$ Despite the fact that the debt was quasi-contractual and between two private parties, the Mississippi Supreme Court said, "[t]o be a debt within the meaning of the Constitution, the obligation existing between the parties must be either purely contractual, or arise from some legal liability growing out of the debtor's dealings with another."286 Most other courts have agreed. ${ }^{287}$

\footnotetext{
28138 So. 730 (Miss. 1905).

282 Id. at 730 .

${ }^{283} I d$.

$284 I d$.

285 Id. at 731.

${ }^{286} I d$. at 730 . The court continued, “The term 'debt,' as employed in a constitutional provision prohibiting the imprisonment therefore, does not extend to or embrace any pecuniary obligation imposed by the state as a punishment for crime, whether the money, the payment of which is demanded, be for fines or costs, or even, in certain quasi criminal proceedings, other penalties of a moneyed nature which may be lawfully inflicted by a court." Id.

287 See, e.g., Lee v. State, 75 Ala. 29, 30 (Ala. 1883) ("[I]t is manifest that fines, forfeitures, mulcts, damagers for a wrong or tort, are not a debt within this clause of the Constitution. ... [W] hen a citizen, by his own misconduct, exposes himself to the punitive powers of the law, the expense incident to his prosecution and conviction, each and all of these may result in subjecting the defaulter to a money liability. These are not debts incurred by contract inter partes, but are the result of being members of the social compact, or body politic.”).
} 
But at least one court has held otherwise. In Strattman v. Studt,288 the defendant was sentenced to the statutory maximum of six months, a fine of $\$ 500$, and costs. 289 After having served his time, and when he couldn't pay his debt, he was imprisoned to "sit out" his debt at $\$ 3$ per day. ${ }^{290}$ The Ohio Supreme Court held that costs are imposed "for the purpose of lightening the burden on taxpayers financing the court system," not for a "punitive, retributive, or rehabilitative purpose, as are fines." ${ }^{291}$ Holding that costs arose out of an "implied contract" with the court, Strattman held that "[a] judgment for costs in a criminal case is a civil, not a criminal, obligation, and may be collected only by the methods provided for the collection of civil judgments." 292 In fact, the ACLU cited Strattman in their letter to Ohio Supreme Court Chief Justice O'Connor, and the bench card promulgated by the court begins as follows: "Fines are separate from court costs. Court costs and fees are civil, not criminal, obligations and may be collected only by the methods provided for the collection of civil judgments." 293

Courts have struggled to land on any consistent treatment of money owed to the government stemming from various noncommercial obligations. The majority rule is that failure to pay income tax falls outside the ban, ${ }^{294}$ as does failure to pay licensing fees, ${ }^{295}$ but a few states have swept income taxes under the meaning of "debt." 296 Similarly, failure to pay a mandatory service charge - such as for inspection services or garbage collection - is generally held to fall outside the scope of the ban, ${ }^{297}$ but the state supreme courts of

\footnotetext{
288253 N.E.2d 749 (Ohio 1969).

289 Id. at 750 .

$290 \mathrm{Id}$. at $750-51$.

291 Id. at 754 .

$292 I d$.

${ }^{293}$ Office of Judicial Services, The Supreme Court of Ohio, Collection of Fines and Court Costs in Adult Trial Courts, https://www.supremecourt.ohio.gov/Publications/JCS/finesCourtCosts.pdf (citing Strattman v. Studt, 253 N.E.2d 749 (Ohio 1969)).

294 See, e.g., People v. Pillon, 171 N.W.2d 484 (Mich. 1969)

295 See, e.g., Austin v. Seattle, 30 P.2d 646, 648 (Wash. 1934) (noting that the "great weight of authority" supports the view that "taxes and license fees are not debt within the purview of such constitutional provisions as ours.").

296 See State v. Higgins, 326 S.E.2d 728, 730 (Ga. 1985) ("We hold that an income tax is a debt - albeit a public debt, as opposed to a private, contractual debt. It is, however, a debt nonetheless. Therefore, we agree that [the challenged statute] is unconstitutional on state law grounds to the extent that it authorizes imprisonment for mere nonpayment of income taxes."); City of Cincinnati v. DeGolyer, 267 N.E.2d 282, 284 (Ohio 1971) ("A tax, like the court costs in a criminal case, is a civil obligation.").

297 See, e.g., Ex parte Small, 221 P.2d 669, 677 (Okla. 1950) (failure to pay garbage collection and DDT spraying fee was more similar to "an expense incident to the
} 
Washington and Iowa have described such obligations as more similar to contractual debts. ${ }^{298}$

If doctrine should follow function, the holding of Strattman should become the law. Even though costs have been constructively treated as punitive, they are fundamentally about funding public services. Insofar as courts need broader discretion in imposing monetary sanctions on criminals for penal purposes, the legislature can simply increase the maximum monetary and nonmonetary sanctions available.

Notwithstanding the difference of opinion among state supreme courts, the U.S. Supreme Court has suggested that costs are civil in a pair of cases from the 1970s: James $v$. Strange 299 and Fuller $v$. Oregon. 300 Depending on how these cases are read, state supreme courts may not be at liberty to treat costs as criminal. Just as the Equal Protection Clause required states to treat indigent and nonindigent debtors similarly, it may also require states to treat certain kinds of civil and quasi-civil debtors similarly.

In James $v$. Strange, the Court struck down a Kansas recoupment statute for costs - at issue was $\$ 500$ of attorneys' fees - when it failed to provide "any of the exemptions provided by [the Kansas Code of Civil Procedure] except the homestead exemption." 301 Acknowledging the wide range of protections afforded under state recoupment laws and therefore resisting a broad holding, ${ }^{302}$ the Court nonetheless expressed concern that the statute "strips from indigent defendants the array of protective exemptions Kansas has erected for other civil judgment debtors," 303 including state exemptions from attachment and restrictions on wage garnishment. ${ }^{304}$ While a state

maintenance of law"); Lavender v. City of Tuscaloosa, 198 So. 459 (Ala. Ct. App. 1940) (holding mandatory privy cleaning fees outside the scope of the ban); Town of Marion v. Baxley, 5 S.E.2d 573 (S.C. 1939) (same for sanitary tax); Benson v. City of Andalusia, 195 So. 443 (Ala. 1940) (same for "sewer service charge").

298 See, e.g., State v. McFarland, 110 P. 792, 794 (Wash. 1910) ("We think . . . that part of [the statute] which makes a mere failure to pay the inspection fee a misdemeanor punishable by fine and imprisonment is clearly unconstitutional as being a violation of [the constitutional ban on] imprisonment for a debt."); Hubbell v. Higgins, 126 N.W. 914 (Iowa 1910) (same).

299407 U.S. 128 (1972).

300417 U.S. 40 (1974).

301 See id. at 131.

302 See id. at 132-33 ("The statutes vary widely in their terms. . . . [A]ny broadside pronouncement on their general validity would be inappropriate.").

${ }^{303} I d$. at 135 (emphasis added).

304 Id. at $135-36$. 
could prioritize its claim to money over other creditors (say, by giving its liens priority), "[t]his does not mean . . . that a State may impose unduly harsh or discriminatory terms merely because the obligation is to the public treasury rather than to a private creditor." 305

In Fuller v. Oregon, the Court upheld an Oregon recoupment statute for costs - fees for an attorney and an investigator ${ }^{306}$ — where a defendant wouldn't be forced to pay unless he was able. ${ }^{307}$ The majority found that the recoupment statute provided all of the same protections, and was therefore "wholly free of the kind of discrimination that was held in James to violate the Equal Protection Clause." 308 Justice Marshall, in dissent, joined by Justice Brennan, cited the Oregon constitutional ban on imprisonment for debt and pointed out that an indigent defendant could be imprisoned for failing to pay his court-appointed lawyer, while "well-heeled defendants" in the same situation could not. ${ }^{309}$ The majority opinion pointed out the issue hadn't been preserved for appeal, ${ }^{310}$ but opined in dicta that the debtors' prison ban was an issue for state courts to decide. ${ }^{311}$ Justice Douglas, concurring in the judgment, agreed, but noted the "apparent inconsistency between Art. $1, \S 19$, and the recoupment statute." 312

While Fuller didn't settle the issue explicitly, both the majority and the dissent (and the Court in James) treated costs as civil debts, which the Equal Protection Clause demands be treated with substantial similarity. Whether or not a debtor can be imprisoned seems rather

\footnotetext{
305 Id. at 138.

306 Fuller v. Oregon, 417 U.S. 40, 42 (1974).

307 See id. at 45-46. The statute seems to have provided for a Bearden-like inquiry: " $[\mathrm{N}] \mathrm{o}$ convicted person may be held in contempt for failure to repay if he shows that "his default was not attributable to an intentional refusal to obey the order of the court or to a failure on his part to make a good faith effort to make the payment." $I d$. at 46 (citing Ore. Rev. Stat. $§ 161.685(2)$ ).

308 Id. at $47-48$.

${ }^{309}$ Id. at 60-61 (Marshall, J., dissenting).

310 See id. at 48 n.9 (majority opinion) ("This contention was not made in the petitioner's brief or oral argument before this Court, and appears not to have been raised in the Oregon courts. It is, therefore, not properly before us."). Justice Douglas agreed the issue wasn't property in front of the Court. See id. at 57 (Douglas, J., concurring) ("I do not believe that this claim was properly preserved below or is properly before this Court.").

311 See id. at 48 n.9 (majority opinion) ("[I]nsofar as the dissent deals with Art. 1, § 19 of the Oregon Constitution which forbids 'imprisonment for debt,' the dissent purports to resolve questions of state law that this Court does not have power to decide.").

${ }^{312}$ Id. at 58 (Douglas, J., concurring); see also id. ("It may be . . . that the Oregon courts would strike down the statutes as being inconsistent with the constitutional provision if they faced the issue.").
} 
central to that similarity test (to put it mildly), and despite the Court's reluctance to rule on an issue not properly briefed, one can see a principled Court confirming in a future case that states must apply their bans on debtors' prison to costs in a criminal case. ${ }^{313}$ In fact, the lawsuits against Ferguson and Jennings made this argument, 314 although they appeal only to equal protection of the laws without citing the Missouri State Constitution: "That no person shall be imprisoned for debt, except for nonpayment of fines and penalties imposed by law." 315 Ultimately, if the states don't adopt the reasoning of Strattman, the Court may well clarify that the Fourteenth Amendment, under Fuller and James, demands it.

\section{Applying Its Protections}

Once a court has determined that a particular monetary obligation counts as "debt" under the ban, it must then determine how to apply the ban's protections. While states differ here, too, the imprisonmentfor-debt tests are more favorable to debtors across the board than the Bearden bona-fide-efforts test. Making out colorable imprisonmentfor-debt claims, while relatively untrodden ground, may have advantages for debtors.

In all states, the ban on imprisonment for debt clamped down on the old writ of capias ad satisfaciendum, or body execution, by which a creditor could petition the court to arrest the debtor until he answered for his debt. ${ }^{316}$ In fact, some states simply passed a law abolishing that writ. What varies from state to state is how the abolition interacts with the general ability of courts to hold contempt proceedings, proceedings that either punish a party for refusing to comply with a court order or coerce a party into complying.

\footnotetext{
313 It may also be worth pointing out that James and Fuller dealt most concretely with attorneys' fees. There's probably no principled reason to distinguish between attorneys' fees and other costs, like a judgment fee or a clerk fee, but doctrinally the Court may have been more aware of making sure defendants weren't being discriminated against for protections states didn't already provide but were required by the Court, such as in its decision mandating counsel for indigent defendants in Gideon v. Wainwright, 372 U.S. 335 (1963).

314 See Complaint, Fant v. Ferguson, at 53 ("The United States Supreme Court has held that, when governments seek to recoup costs of prosecution from indigent defendants, they may not take advantage of their position to impose unduly harsh methods of collection solely because debt is owed to the government and not to a private creditor."); Complaint, Jenkins v. Jennings, at 58-59.

315 Mo. Const. art. I, § 11.

316 Some states, as noted above, abolished the writ. Others, like New Jersey, modified the conditions under which it could be imposed. See Perimutter v. DeRowe, 274 A.2d 283 (N.J. 1971); Note, supra note 158, at 853.
} 
Some states have held that their bans on imprisonment for debt remove the ability of a court to issue contempt orders for nonpayment of qualifying debts. ${ }^{317}$ This is the "no-hearing rule." That is, after the substantive case, the court may declare a money judgment, and the judgment creditor may pursue execution proceedings, attempting to attach nonexempt property or garnish wages. But the judgment creditor may not move the court to issue a civil contempt order to coerce the debtor into paying, and the court may not do so sua sponte.

Even in states where courts have held that the ban does not comprise a blanket removal of authority to hold contempt proceedings, most courts require a sharply limited (and debtor-favorable) inquiry. Courts emphasize that the contempt lies in failing to comply with an injunction to turn over specific property that is currently under the debtor's control. ${ }^{318}$ An injunction as a general rule is a "drastic and extraordinary remedy." 319 And that specific property must also be nonexempt under the state's exemption laws, ${ }^{320}$ provisions that in every state exempt a certain amount of personal property from attachment and garnishment. Moreover, some states require that

${ }^{317}$ E.g., In re Nichols, 749 So.2d 68 (Miss. 1999) ("The [creditors] are free to collect the judgment by execution, garnishment, or any other available lawful means so long as it does not include imprisonment.").

318 See, e.g., Harrison v. Harrison, 394 S.W.2d 128, 130 (Ark. 1965) (noting that the contempt lies in concealing specific money or property ordered to be turned over, especially property on which the creditor had obtained an equitable lien). In Lepak $v$. McClain, 844 P.2d 852 (Okla. 1992), the Oklahoma Supreme Court sustained the contempt of court power when used "to require the delivery of . . . identified property owned by and in the possession or control of the judgment debtor ... if the judgment debtor unjustly refuses to apply the identified property towards the satisfaction of a judgment," id. at 855, but struck it down under the ban on imprisonment for debt when contempt was used to "require the judgment debtor to set aside and deliver a portion of his/her future income toward the satisfaction of the judgment debt," $i d$. At an initial pass, states with cases affirming this rule include the following: Oklahoma, see Lepak v. McClain, 844 P.2d 852, 855 (Okla. 1992) (striking down contempt statute requiring debtor to pay out of future earnings); Sommer v. Sommer, 947 P.2d 512, 519 (Okla. 1997) (upholding contempt order that required debtor to "deliver specific property in existence at the time of the order"), Utah, see In re Clift's Estate, 159 P.2d 872 (1945) ("Even where the violation of the order is the failure to pay over money for the recovery of which a judgment has been entered on which an execution may issue, if the order is one which the court could lawfully make the imprisonment is not for the failure to pay the debt, but because of the failure to obey a lawful order of the court which constitutes contempt of court."), and Missouri, see Zeitinger v. Mitchell, 244 S.W.2d 91, 97-98 (1951) (citing In re. Clift's Estate, 159 P.2d); Stanhope v. Pratt, 533 S.W.2d 567, 574-75 (1976) (discussing rule that failure to turn over specific assets found to be in possession of the debtor could lead to contempt).

319 Monsanto Co. v. Geertson Seed Farms, 130 S. Ct. 2743, 2761 (2010).

320 See, e.g., Shepard, supra note 188, at 1531-32. 
creditors attempt execution through in rem actions, before resorting to in personam actions. ${ }^{321}$

Under either of these rules, then, debtors face a much more friendly inquiry than they would under Bearden. Instead of a bona-fide-efforts test that asks whether they've sought employment or credit to pay off the debt, the inquiry would be instead whether the court had identified specific, nonexempt property then under the control of the debtor that the debtor was ordered to turn over. Under such a test, a "specificnonexempt-assets" test, the determinative factor in an easy debtor victory in most cases would be the debtor showing up with minimal knowledge of her rights. ${ }^{322}$ In other states, the court simply could not imprison for failure to pay the debt, although it could pursue other execution remedies available at law. ${ }^{323}$ Such a result could dramatically lower the litigation costs of the public-interest bar.

\section{New Abolitionism}

The foregoing analysis has focused on constitutional and statutory interpretation. The key legal actors have therefore been courts. Just as this Article's focus on imprisonment-for-debt provisions points out that federal courts aren't the only courts that matter, so too we must realize courts themselves are not the only institutional actors whose views are relevant to our shared ethical life. The problem of the new debtors' prisons is so serious, for the reasons described above, that entrusting the entire solution to the courts makes little sense, especially as some interpretive principles, like stare decisis, tug against the reinterpretations proposed here.

First, state constitutions could be amended, although the political action costs of doing so may well be too steep. None of the lists of bans of debtors' prisons in the literature focuses on how the provisions

\footnotetext{
321 See id. at 1529-30 (describing the rule and its principle in the common law rule that creditors would have to exhaust legal remedies before turning to equitable remedies).

322 Shepard, for example, points out that most debtors in such proceedings are unrepresented and unaware of their exemption rights. See id. at 1533. And creditors often win on default when debtors don't show up. Id. at 1534-35. It's particularly important that debtors know their rights, so they don't voluntarily give over exempt assets, and that they show up, so that they aren't arrested for nonappearance contempt. See id. at 1537.

323 Of course, there's some concern that a punitively minded state might respond by attempting to roll back the protections of its exemption statute. But such a change would affect both civil debtors in addition to the criminal debtors discussed here, creating an unlikely (but intuitive) coalition that could create some pushback.
} 
changed over time, ${ }^{324}$ but some of them have been amended several times. In fact, at least some of the provisions that currently read as a flat ban ("There shall be no imprisonment for debt") previously had carve-outs and exceptions in them, which were subsequently removed. ${ }^{325}$ Indeed, some courts have focused on the history of constitutional amendments when interpreting the text of the ban. ${ }^{326}$ In particular, local abolitionist movements should consider pushing for constitutional amendments to match the broadest possible formation: "There shall be no imprisonment for debt." The nine states without such constitutional provisions should consider adding them. Such a constitutional amendment would likely be interpreted by reviewing courts as being intended to address our contemporary "mischief": the new debtors' prisons. The core exceptions for criminal fines, taxes, alimony, and child support payments would not be jeopardized by such new legal texts since - as noted above - they have readily been interpreted out of the bans.

Second, just because a state constitution fails to ban debtors' prisons doesn't mean we have to construct them. There's no constitutional requirement that we imprison people for failing to pay their debts. For costs and strict-liability crimes, state and federal legislators should consider passing statutes requiring courts to use only those tools available to civil debtors in the collection of criminal debts. For fines, legislators should explicitly require courts to comply with the U.S. Constitution under Bearden and, like Ohio, provide resources to help courts swiftly move through backed-up dockets, such as establishing a fair and fast presumption of indigence on a finding of SNAP-eligibility.

And building a social movement can be more effective than litigation or constitutional referenda, especially when it's buttressed by sound legal arguments. ACLU Senior Staff Counsel Eric Balaban has described how the ACLU built a public movement in Ohio by filing requests for public records, court-watching, sending letters to judges

\footnotetext{
${ }^{224}$ See, e.g., Vogt, supra note 38, at 335 n.9; Conway, supra note 149, at 1679 n.1. 325 See supra note 153 (discussing the evolution of Georgia's constitutional ban.). ${ }^{326}$ In Carr v. State, 17 So. 350 (Ala. 1895), the Alabama Supreme Court noted that the current constitution's lack of an exception for "cases of fraud" was different from the Alabama constitutions of 1819, 1861, and 1865. See id. at 351. The court said, In Ex parte Hardy, 68 Ala. 303, 318, it was held - and we do not understand that there was any division of opinion on this point - that the elimination of the exception as to frauds was a pregnant omission, which left the guaranty of immunity from imprisonment to the debtor to apply to all cases of debt, whether they involved fraud or not. Id.
} 
and court administrators, and collecting data. ${ }^{327}$ Given the range of responses detailed above — judgments, settlements, bench cards, legislation - it would be foolish to rely on one method of legal change alone.

\section{Chilling "Credit” \& Backlash}

As this point, it becomes important to address a key counterargument. Removing a coercive sanction for repayment of debt will make that debt - on the whole - less valuable to the creditor. In the private context, as discussed above, this may make it difficult for certain individuals and groups to obtain credit. In the criminal context, the state qua lender may pull back on the extension of credit in a parallel way, by cutting back on procedural expenses, by using imprisonment as a sanction for more offenses, by amending the authorizing statutes, or by altering sentencing practices. A reinvigorated ban on the debtors' prison executed purely through the judicial interpretation of constitutional texts - when the legislative and executive branches are not on board - faces the very practical concern that the government will respond to judicial action in ways that undermine the ultimate policy objective. In other words, what about backlash?328

While these concerns are valid, there are a number of reasons to suspect it isn't weighty enough to carry the day - although empirical work might shed better light on the matter. First, just as nonzero transaction costs mean that initial allotments of legal rights aren't always shifted, nonzero "political action costs" suggest that a successful ban won't automatically result in more incarceration ex ante or narrower procedural safeguards. ${ }^{329}$ This is especially true as the New Abolition of debtors' prisons, as described above, is limited in scope to those areas that seem the most unfair and the least functionally necessary. Second, insofar as states are motivated by filling their coffers, the ban simply rules out one of the most regressive ways of doing so. And insofar as states are motivated by the traditional objectives of penal law, the ban simply requires that punishment not be hidden in the guise of imprisonment for

327 See Balaban supra note 67.

328 For an overview of the "backlash" thesis in the context of Brown v. Board of Education, see Michael J. Klarman, How Brown Changed Race Relations: The Backlash Thesis, 81 J. AM. HisT. 81 (1994).

${ }^{329}$ For a theoretical discussion of political action costs, see Lee Anne Fennell \& Richard H. McAdams, The Distributive Deficit in Law and Economics, MinN. L. REV. (forthcoming 2015), available http://papers.ssrn.com/sol3/papers.cfm?abstract_id=2544519. 
nonpayment of debt. Authorization statutes, enabling sentencing courts to impose imprisonment or monetary fines, can be amended if necessary. Finally, federal constitutional law provides safeguards. Assuming a constant quantum of punishment per case, forcing it into one doctrinal location enables the Eighth Amendment, say, to regulate it more cleanly. And there are independent backstops on the minimum procedures governments may use, namely, the Fifth and Fourteenth Amendments.

Additionally, imprisonment-for-debt claims and state-by-state legislation would minimize backlash concerns. Unlike the main case studies that drive the backlash thesis, Brown v. Board of Education ${ }^{330}$ and Roe v. Wade, ${ }^{331}$ the chief doctrinal argument here interprets state constitutional texts. The specter of a heavy-handed federal government imposing its will on the states isn't nearly as concerning here. Federalism concerns are at a nadir. Furthermore, regarding the countermajoritarian difficulty, the argument doesn't address itself only to the judiciary: insofar as its argument calls for a certain moral, economic, and legal conviction, the solution should be carried out by the full range of legal actors, including legislative and executive.

\section{CONCLUSION}

There are many things wrong with mass incarceration. One of them is rampant imprisonment for debt. The new debtors' prisons take a different doctrinal form, and they're not exactly the historic heirs of the old ones - but on a deeper level, they trigger the same concerns that precipitated the abolition of their predecessors. Our shared history and values demand that a new abolitionist movement dismantle the new American debtors' prisons, just as we did the old.

\footnotetext{
330347 U.S. 483 (1954).
}

331410 U.S. 113 (1973). 